\title{
Modelling the structural and reactivity landscapes of tucatinib with special reference to its wavefunction-dependent properties and screening for potential antiviral activity
}

\author{
Ali Alsalme ${ }^{1} \cdot$ T. Pooventhiran $^{2} \cdot$ Nabil Al-Zaqri $^{1} \cdot$ D. Jagadeeswara Rao ${ }^{3} \cdot$ Siriki Srinivasa Rao $^{4} \cdot$ Renjith Thomas $^{2}$ (D)
}

Received: 26 August 2020 / Accepted: 8 November 2020 / Published online: 16 November 2020

(C) Springer-Verlag GmbH Germany, part of Springer Nature 2020

\begin{abstract}
HER-2 type breast cancer is one of the most aggressive malignancies found in women. Tucatinib is recently developed and approved as a potential medicine to fight this disease. In this manuscript, we present the gross structural features of this compound and its reactivity and wave function properties using computational simulations. Density functional theory was used to optimise the ground state geometry of the molecule and molecular docking was used to predict biological activity. As the electrons interact with electromagnetic radiations, electronic excitations between different energy levels are analysed in detail using timedependent density functional theory. Various intermolecular and intermolecular interactions are analysed and reaction sites for attacking electrophiles and nucleophiles identified. Information entropy calculations show that the compound is inherently stable. Docking with COVID-19 proteins show docking score of $-9.42,-8.93,-8.45$ and $-8.32 \mathrm{kcal} / \mathrm{mol}$ respectively indicating high interaction between the drug and proteins. Hence, this is an ideal candidate to study repurposing of existing drugs to combat the pandemic.
\end{abstract}

Keywords DFT $\cdot$ Tucatinib $\cdot$ Docking $\cdot$ NCI $\cdot$ LIE

\section{Introduction}

Breast cancer is one of the most common type of neoplasm found in women and it is divided basically into different subtypes, viz., Luminal A, Luminal B, HER2-enriched, Basallike and the human epidermal growth factor receptor-2enriched (HER2-E) is indicated by the overexpression of growth factor receptor-related genes and cell cycle-related genes along with low presence of oestrogen-related and basal-related genes [1-3]. Always, there is a risk of metastatic spread to other interorgans like lungs, brain and bone $[4,5]$.

Renjith Thomas

renjith@sbcollege.ac.in

1 Department of Chemistry, College of Science, King Saud University, P.O. Box 2455, Riyadh 11451, Saudi Arabia

2 Department of Chemistry, St. Berchmans College (Autonomous), Changanassery, Kerala, India

3 Department of Physics, Dr. Lankapalli Bullayya College, Visakhapatnam, Andhra Pradesh, India

4 Department of Physics, Mrs. A.V.N.College, Visakhapatnam, Andhra Pradesh, India
HER2 tyrosine kinase inhibitor Lapatinib is widely used for the management of this disease [6]. Tucatinib is recently developed as a promising drug for the management of HER2positive breast cancer [7]. It is also used along with trastuzumab in patients with HER2-positive colorectal cancer [8]. Tucatinib even showed extensive anti-tumour activity and tumour regression in N87 gastric cancer cell line and HER2amplified colorectal, oesophageal and gastric cancers [9, 10]. The drug is also well tolerated in patients also along with trastuzumab [11].

Recently, the new strain of coronavirus, $n-C o V-2$, is devastating human life in entire globe which now emerged to the dimensions of a pandemic and had impacted the life style and health of almost all the people [12]. Scientists through the globe are tirelessly working for establishing the pathology [13], epidemiology [13] and many are try to develop novel molecules, antibodies and vaccines [14]. As it is difficult to come with a new magic molecule which could cure this disease in a short period of time, scientists are looking to reroute the existing drugs with known pharmacokinetics and pharmacodynamics for the management of COVID [15-17]. Chloroquine was once highlighted as a wonder medicine for the management of COVID, in spite of several differences in 
opinions about its effectiveness and now discontinued [18]. Remdesivir is now presently used widely to get rid of the pneumonia associated with COVID [19]. Lopinavir, umifenovir, favipiravir and oseltamivir molecules are also used now as a potentially active compound against the virus [15]. Thomas and coworkers recently reported that the sleep hormonemelatonin has preferential binding over the COVID proteins [20]. As it is time consuming to design and develop a drug for the treatment, it will be a wise decision to do research to reroute the existing drugs as a molecular target against the virus. We also thought in this direction and decided to screen tucatinib as a potential candidate for the management of COVID.

Understanding the electronic structure of a compound is very important for analysing the potential applications of a compound. Literature analysis showed that no studies have been reported in this direction. This manuscript attempts to study the detailed geometry, electronic structure, physical and chemical properties, orbital characteristics, surface topology, non-covalent interactions, electronic excitations, intermolecular stabilisations and information entropy analysis. It is followed by molecular modelling studies of the interaction of the molecule with four prominent $\mathrm{n}-\mathrm{CoV}-19$ proteins. We believe that this manuscript will be an addition to the scientific data.

\section{Methods}

We report the detailed study of the molecule using molecular simulations. Tucatinib molecule was optimised using Gaussian-09 [21] software, a package using DFT methodology with $\omega$ B97XD [22-24] functional and cc-pVDZ basis set [25]. We performed the frequency calculations to ensure that there exists no imaginary frequency such that the obtained geometry corresponds to a global minimum for reaching the optimised geometry. We used the same geometry for calculating frontier molecular analysis, natural bonding orbitals and non-linear optical studies. For UV-visible spectrum simulation, we used time-dependent density functional theory (TDDFT) with long-range corrected CAM-B3LYP functional [26, 27] and aug-cc-pVDZ basis set as the electronic transitions are time-dependent phenomena with GaussSum [28]. Reaction sites of tucatinib calculated using Multiwavefunction [29] software for calculating total electrostatic, average localised ionisation energy, electron localisation functions, localised orbital locator, reduced density gradient, localised entropy interaction, electron delocalisation functions, local electron locator, reduced density gradient and non-covalent interactions for tucatinib's anti-coronovirus 2 biological activity were analysed by using suitable proteins in the PDB format downloaded from RCSB [30] site, the energy received from SwissDock and the score values received from PatchDock
[31] after docking and the docked results analysed using bio-discovery studio.

\section{Results and discussion}

\section{Geometry structure for tucatinib}

Tucatinib molecular structure was optimised by using density functional theory method for structural confirmation, DFT- $\omega$ B97XD as a method, and cc-pVDZ as a basis set. The optimised structure for tucatinib is shown in Fig. 1 and Table 1 shows important bond distances and angles for

Table 1 Structural parameters of tucatinib

\begin{tabular}{|c|c|c|c|}
\hline Definition & Value (in $\AA$ ) & Definition & Value (in $\left.{ }^{\circ}\right)$ \\
\hline $\mathrm{R}(1 \mathrm{O}-12 \mathrm{C})$ & 1.44 & $\mathrm{~A}(12 \mathrm{C}-1 \mathrm{O}-15 \mathrm{C})$ & 105.18 \\
\hline $\mathrm{R}(1 \mathrm{O}-15 \mathrm{C})$ & 1.36 & $\mathrm{~A}(26 \mathrm{C}-2 \mathrm{O}-31 \mathrm{C})$ & 118.20 \\
\hline $\mathrm{R}(2 \mathrm{O}-26 \mathrm{C})$ & 1.39 & $\mathrm{~A}(11 \mathrm{C}-3 \mathrm{~N}-15 \mathrm{C})$ & 106.35 \\
\hline $\mathrm{R}(2 \mathrm{O}-31 \mathrm{C})$ & 1.36 & $A(15 C-4 N-16 C)$ & 127.74 \\
\hline $\mathrm{R}(3 \mathrm{~N}-11 \mathrm{C})$ & 1.48 & $\mathrm{~A}(15 \mathrm{C}-4 \mathrm{~N}-45 \mathrm{H})$ & 114.54 \\
\hline $\mathrm{R}(3 \mathrm{~N}-15 \mathrm{C})$ & 1.28 & $\mathrm{~A}(16 \mathrm{C}-4 \mathrm{~N}-45 \mathrm{H})$ & 117.67 \\
\hline $\mathrm{R}(4 \mathrm{~N}-15 \mathrm{C})$ & 1.36 & $\mathrm{~A}(21 \mathrm{C}-5 \mathrm{~N}-23 \mathrm{C})$ & 131.47 \\
\hline $\mathrm{R}(4 \mathrm{~N}-16 \mathrm{C})$ & 1.39 & $\mathrm{~A}(21 \mathrm{C}-5 \mathrm{~N}-49 \mathrm{H})$ & 114.73 \\
\hline $\mathrm{R}(4 \mathrm{~N}-45 \mathrm{H})$ & 1.01 & $\mathrm{~A}(23 \mathrm{C}-5 \mathrm{~N}-49 \mathrm{H})$ & 113.77 \\
\hline $\mathrm{R}(5 \mathrm{~N}-21 \mathrm{C})$ & 1.37 & $\mathrm{~A}(20 \mathrm{C}-6 \mathrm{~N}-29 \mathrm{C})$ & 115.19 \\
\hline $\mathrm{R}(5 \mathrm{~N}-23 \mathrm{C})$ & 1.40 & $\mathrm{~A}(21 \mathrm{C}-7 \mathrm{~N}-29 \mathrm{C})$ & 117.13 \\
\hline $\mathrm{R}(5 \mathrm{~N}-49 \mathrm{C})$ & 1.01 & $\mathrm{~A}(10 \mathrm{~N}-8 \mathrm{~N}-33 \mathrm{C})$ & 110.27 \\
\hline $\mathrm{R}(6 \mathrm{~N}-20 \mathrm{C})$ & 1.37 & $\mathrm{~A}(10 \mathrm{~N}-8 \mathrm{~N}-35 \mathrm{C})$ & 126.30 \\
\hline $\mathrm{R}(6 \mathrm{~N}-29 \mathrm{C})$ & 1.31 & $\mathrm{~A}(33 \mathrm{C}-8 \mathrm{~N}-35 \mathrm{C})$ & 123.43 \\
\hline $\mathrm{R}(7 \mathrm{~N}-21 \mathrm{C})$ & 1.32 & $\mathrm{~A}(33 \mathrm{C}-9 \mathrm{~N}-36 \mathrm{C})$ & 102.33 \\
\hline $\mathrm{R}(7 \mathrm{~N}-29 \mathrm{C})$ & 1.36 & $\mathrm{~A}(8 \mathrm{~N}-10 \mathrm{~N}-36 \mathrm{C})$ & 101.28 \\
\hline $\mathrm{R}(8 \mathrm{~N}-10 \mathrm{C})$ & 1.35 & $\mathrm{~A}(1 \mathrm{O}-15 \mathrm{C}-3 \mathrm{~N})$ & 119.22 \\
\hline $\mathrm{R}(8 \mathrm{~N}-33 \mathrm{C})$ & 1.38 & $\mathrm{~A}(1 \mathrm{O}-15 \mathrm{C}-4 \mathrm{~N})$ & 112.02 \\
\hline $\mathrm{R}(8 \mathrm{~N}-35 \mathrm{C})$ & 1.36 & $A(3 N-15 C-4 N)$ & 128.77 \\
\hline $\mathrm{R}(9 \mathrm{~N}-33 \mathrm{C})$ & 1.33 & $\mathrm{~A}(18 \mathrm{C}-17 \mathrm{C}-20 \mathrm{C})$ & 120.68 \\
\hline $\mathrm{R}(9 \mathrm{~N}-36 \mathrm{C})$ & 1.35 & $\mathrm{~A}(18 \mathrm{C}-17 \mathrm{C}-21 \mathrm{C})$ & 124.02 \\
\hline $\mathrm{R}(10 \mathrm{~N}-36 \mathrm{C})$ & 1.33 & $A(20 C-17 C-21 C)$ & 115.29 \\
\hline $\mathrm{R}(24 \mathrm{C}-30 \mathrm{C})$ & 1.50 & $\mathrm{~A}(5 \mathrm{~N}-21 \mathrm{C}-7 \mathrm{~N})$ & 120.56 \\
\hline $\mathrm{R}(26 \mathrm{C}-28 \mathrm{C})$ & 1.39 & $\mathrm{~A}(5 \mathrm{~N}-21 \mathrm{C}-17 \mathrm{C})$ & 118.20 \\
\hline $\mathrm{R}(28 \mathrm{C}-52 \mathrm{H})$ & 1.09 & $A(7 N-21 C-17 C)$ & 121.24 \\
\hline \multirow[t]{9}{*}{$\mathrm{R}(31 \mathrm{C}-32 \mathrm{C})$} & 1.37 & $\mathrm{~A}(5 \mathrm{~N}-23 \mathrm{C}-25 \mathrm{C})$ & 124.34 \\
\hline & & $\mathrm{A}(5 \mathrm{~N}-23 \mathrm{C}-27 \mathrm{C})$ & 116.38 \\
\hline & & $\mathrm{A}(25 \mathrm{C}-23 \mathrm{C}-27 \mathrm{C})$ & 119.28 \\
\hline & & $\mathrm{A}(31 \mathrm{C}-32 \mathrm{C}-33 \mathrm{C})$ & 117.93 \\
\hline & & $\mathrm{A}(31 \mathrm{C}-32 \mathrm{C}-57 \mathrm{H})$ & 122.84 \\
\hline & & $\mathrm{A}(33 \mathrm{C}-32 \mathrm{C}-57 \mathrm{H})$ & 119.23 \\
\hline & & $\mathrm{A}(8 \mathrm{~N}-33 \mathrm{C}-9 \mathrm{~N})$ & 109.08 \\
\hline & & $\mathrm{A}(8 \mathrm{~N}-33 \mathrm{C}-32 \mathrm{C})$ & 118.91 \\
\hline & & $\mathrm{A}(9 \mathrm{~N}-33 \mathrm{C}-32 \mathrm{C})$ & 132.01 \\
\hline
\end{tabular}


tucatinib. The molecule possesses three heterocyclic rings, ether and secondary anime linkages connecting the rings.

The bond distances for $1 \mathrm{O}-12 \mathrm{C}, 1 \mathrm{O}-15 \mathrm{C}, 2 \mathrm{O}-26 \mathrm{C}, 2 \mathrm{O}$ $31 \mathrm{C}, 3 \mathrm{~N}-11 \mathrm{C}, 3 \mathrm{~N}-15 \mathrm{C}, 4 \mathrm{~N}-15 \mathrm{C}, 4 \mathrm{~N}-16 \mathrm{C}, 4 \mathrm{~N}-45 \mathrm{H}, 5 \mathrm{~N}-$ $21 \mathrm{C}, 5 \mathrm{~N}-23 \mathrm{C}, 5 \mathrm{~N}-49 \mathrm{C}, 6 \mathrm{~N}-20 \mathrm{C}, 6 \mathrm{~N}-29 \mathrm{C}, 7 \mathrm{~N}-21 \mathrm{C}, 7 \mathrm{~N}-$ $29 \mathrm{C}, 8 \mathrm{~N}-10 \mathrm{C}, 8 \mathrm{~N}-33 \mathrm{C}, 8 \mathrm{~N}-35 \mathrm{C}, 9 \mathrm{~N}-33 \mathrm{C}, 9 \mathrm{~N}-36 \mathrm{C}, 10 \mathrm{~N}-$ $36 \mathrm{C}, 24 \mathrm{C}-30 \mathrm{C}, 26 \mathrm{C}-28 \mathrm{C}, 28 \mathrm{C}-52 \mathrm{H}$ and $31 \mathrm{C}-32 \mathrm{C}$ having $1.44,1.36,1.39,1.36,1.48,1.28,1.36,1.39,1.01,1.37$, $1.40,1.01,1.37,1.31,1.32,1.36,1.35,1.38,1.36,1.33$, $1.35,1.33,1.50,1.39,1.09$ and $1.37 \AA$ respectively. The bond angles for $12 \mathrm{C}-1 \mathrm{O}-15 \mathrm{C}, 26 \mathrm{C}-2 \mathrm{O}-31 \mathrm{C}, 11 \mathrm{C}-3 \mathrm{~N}-15 \mathrm{C}, 15 \mathrm{C}-$ $4 \mathrm{~N}-16 \mathrm{C}, 15 \mathrm{C}-4 \mathrm{~N}-45 \mathrm{H}, 16 \mathrm{C}-4 \mathrm{~N}-45 \mathrm{H}, 21 \mathrm{C}-5 \mathrm{~N}-23 \mathrm{C}, 21 \mathrm{C}-$ $5 \mathrm{~N}-49 \mathrm{H}, 23 \mathrm{C}-5 \mathrm{~N}-49 \mathrm{H}, 20 \mathrm{C}-6 \mathrm{~N}-29 \mathrm{C}, 21 \mathrm{C}-7 \mathrm{~N}-29 \mathrm{C}, 10 \mathrm{~N}-$ $8 \mathrm{~N}-33 \mathrm{C}, 10 \mathrm{~N}-8 \mathrm{~N}-35 \mathrm{C}, 33 \mathrm{C}-8 \mathrm{~N}-35 \mathrm{C}, 33 \mathrm{C}-9 \mathrm{~N}-36 \mathrm{C}, 8 \mathrm{~N}-$ $10 \mathrm{~N}-36 \mathrm{C}, 1 \mathrm{O}-15 \mathrm{C}-3 \mathrm{~N}, 1 \mathrm{O}-15 \mathrm{C}-4 \mathrm{~N}, 3 \mathrm{~N}-15 \mathrm{C}-4 \mathrm{~N}, 18 \mathrm{C}-$ $17 \mathrm{C}-20 \mathrm{C}, 18 \mathrm{C}-17 \mathrm{C}-21 \mathrm{C}, 20 \mathrm{C}-17 \mathrm{C}-21 \mathrm{C}, 5 \mathrm{~N}-21 \mathrm{C}-7 \mathrm{~N}$, $5 \mathrm{~N}-21 \mathrm{C}-17 \mathrm{C}, 7 \mathrm{~N}-21 \mathrm{C}-17 \mathrm{C}, 5 \mathrm{~N}-23 \mathrm{C}-25 \mathrm{C}, 5 \mathrm{~N}-23 \mathrm{C}-27 \mathrm{C}$, $25 \mathrm{C}-23 \mathrm{C}-27 \mathrm{C}, 31 \mathrm{C}-32 \mathrm{C}-33 \mathrm{C}, 31 \mathrm{C}-32 \mathrm{C}-57 \mathrm{H}, 33 \mathrm{C}-32 \mathrm{C}-$ $57 \mathrm{H}, 8 \mathrm{~N}-33 \mathrm{C}-9 \mathrm{~N}, 8 \mathrm{~N}-33 \mathrm{C}-32 \mathrm{C}$ and $9 \mathrm{~N}-33 \mathrm{C}-32 \mathrm{C}$, having $105.18,118.20,106.35,127.74,114.54,117.67,131.47$, $114.73,113.77,115.19,117.13,110.27,126.30,123.43$, $102.33,101.28,119.22,112.02,128.77,120.68,124.02$, $115.29,120.56,118.20,121.24,124.34,116.38,119.28$, $117.93,122.84,119.23,109.08,118.91$ and $132.01^{\circ}$ respectively.

\section{Frontier molecular orbital (FMO) properties for tucatinib}

Frontier molecular orbitals can provide valuable information the energy band gap and using the HOMO and LUMO energy, one can predict various physical and chemical descriptors of the molecule, which enables us to comment on the reactivity, stability and biological activity [32]. The energies are calculated in the DFT- $\omega$ B97XD/cc-pVDZ basis set and the related data is presented in Table 2. HOMO is the molecule is found to have energy $-5.59 \mathrm{eV}$ and LUMO $-1.50 \mathrm{eV}$. The energy gap is only $4 \mathrm{eV}$. The ionisation energy $[33,34]$ is $5.50 \mathrm{eV}$ and electron affinity $1.59 \mathrm{eV}$ [35-38]. Global hardness $[39,40]$ and softness [41] are widely regarded as an indicator of the reactivity of compounds, whose values are $2.00 \mathrm{eV}$ and $0.50 \mathrm{eV}$ respectively. The softness value is high such that the compound is polarisable and hence more chance to be biologically active. The chemical potential, which is the average of ionisation energy and electron affinity is found to $-3.59 \mathrm{eV}$, which indicates that the molecule is reactive [42]. The electronegativity [43] was $3.59 \mathrm{eV}$. The compound is electrophilic (see the $[44,45]$ and nucleophilicity index [46-49] values) in nature with a negative electrondonating power. This is in agreement with the high electron affinity values. Hence, it can be concluded that the compound is

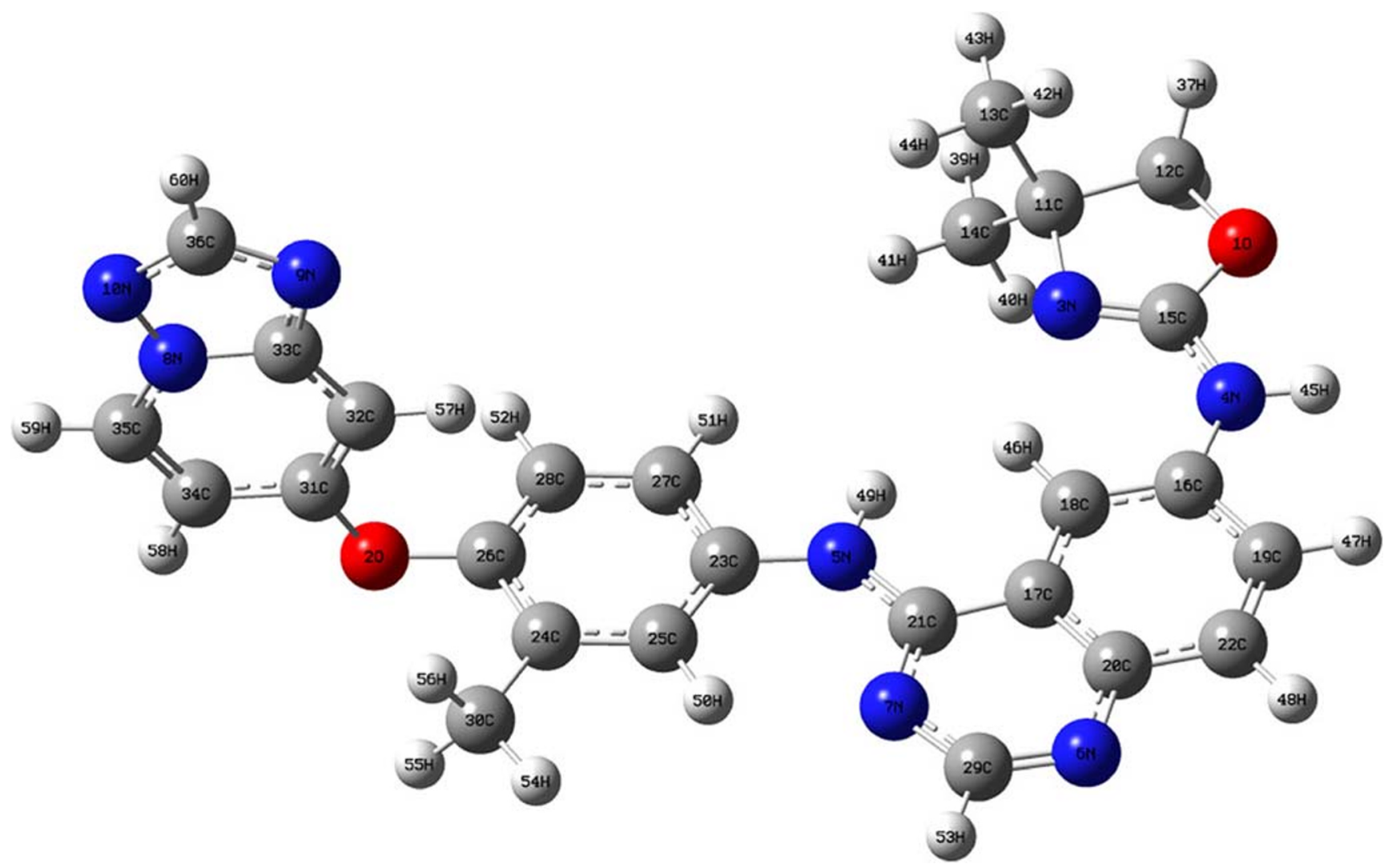

Fig. 1 Geometry structure for tucatinib 
Table 2 Frontier molecular orbitals properties for tucatinib

\begin{tabular}{lr}
\hline Property & Values \\
\hline HOMO $(\mathrm{eV})$ & -5.59 \\
LUMO $(\mathrm{eV})$ & -1.59 \\
Energy gap $\Delta E(\mathrm{eV})$ & 4.00 \\
Ionisation energy $(I=\varepsilon \mathrm{HOMO}=-\mathrm{HOMO})(\mathrm{eV})$ & 5.59 \\
Electron affinity $(A=\varepsilon \mathrm{LUMO}=-\mathrm{LUMO})(\mathrm{eV})$ & 1.59 \\
Global hardness $(\eta=(I-A) / 2)(\mathrm{eV})$ & 2.00 \\
Global softness $(S=1 / \eta)$ & 0.50 \\
Chemical potential $(\mu=-(I+A) / 2)(\mathrm{eV})$ & 3.59 \\
Electronegativity $(\chi=-\mu)(\mathrm{eV})$ & 3.59 \\
Electrophilicity index $(\omega=\mu 2 / 2 \eta)$ & 3.22 \\
Nucleophilicity index $(N=1 / \omega)$ & 0.31 \\
$\Delta N$ max & 1.79 \\
Electroaccepting power $\omega+=A 2 / 2(I-A)$ & 0.31 \\
Electrodonating power $\omega+=I 2 / 2(I-A)$ & 37.63 \\
\hline
\end{tabular}

inherently reactive and this feature is responsible for various biological activities.

\section{Time-dependent density functional theory study for tucatinib}

Being a time-dependent phenomenon, the electronic transitions and consequently the electronic spectra of compounds cannot be modelled by DFT simulations, instead has to use time-dependent (TD-DFT) simulations which employs Tamm-Dancoff approximations [50, 51]. We used TD-DFT simulations with CAMB3LYP functional and cc-pVDZ as a basis set using IEFPCM [52] solvation model with methanol as solvent. The ultraviolet-visible spectrum and the different orbitals involved in the transition are given in Figs. 2 and 3 and Table 3.

Simulation shows that there are three electronic transitions possible and among them, only two are significant. The first peak was observed at wavelength is $309.24 \mathrm{~nm}$ with oscillator strength is 0.44 . It is with singlet asymmetry and the major reasons of this peak is the transition from higher occupied molecular orbital (HOMO) to lower unoccupied molecular orbital (LUMO) with 90 percentage contribution. The second significant peak was at $267.56 \mathrm{~nm}$ with oscillator strength of 0.26 , and singlet asymmetry. This peak is due to electronic transitions from second last higher occupied molecular orbital
(HOMO-2) to lower unoccupied molecular orbital (LUMO) with contribution 12 percentage, and from higher occupied molecular orbital (HOMO) to second lower unoccupied molecular orbital $(\mathrm{LUMO}+2)$ with 60 percentage contribution. For the first transition, oscillator strength $(f)$ is 0.4431 , which means, the molecule is having good light-harvesting efficiency (LHE), which is expressed as a function of the oscillator strength related as LHE $=1-10^{-\mathrm{f}}[53-56]$. The value is 0.6395 for the first transition, which indicate that the compound can absorb $63.95 \%$ of the incident light energy for electronic excitation at that particular wavelength $[57,58]$.

\section{Non-linear optical properties for tucatinib}

Study of light matter interactions is very important especially for organic molecules. Recently, a large number of organic non-linear optical (NLO) compounds have been extensively studied using various computational tools for their potential industrial use [59-61]. The ability of the molecule to bend the linear light can be done using the polarisability and hyperpolarisability values obtained from the Raman spectrum simulation. This type of non-linear optical activity is very important for using the compound in organic electronics industry [62-64]. The simulation is carried out in the same theoretical level as of the optimisation and is compared with a standard non-linear optically active substance urea and $p$ nitroacetanilide (PNA) [65, 66]. The non-linear optical property parameters for tucatinib are shown in Table 4 . Tucatinib is found to have dipole moment $(\mu)$ of $2.74 \mathrm{D}$, which is 1.58 times greater than urea and 3.01 times greater than $p$-nitro acetanilide. Hyperpolarisability $(\beta)$ is $51.60 * 10^{-31}$ e.s.u., which is 6.79 times greater than urea and 0.21 times than $p$ nitro acetanilide. The high values of values are due to the highly non-symmetric structure of the compound $\left(C_{\mathrm{s}}\right.$ point group).

\section{Nature bond orbital analysis for tucatinib}

Intramolecular electron displacements are very important as they decide the inherent stability of a compound. Natural bond orbital analysis is an excellent tool to study such interactions via hyperconjugation [67-72]. The occupancy values of the natural bond orbitals and their deloclaisation energy provide valuable information about the above-mentioned stabilisations. Nature bond orbital (NBO) calculations were

Table 3 Electronic transitions in tucatinib

\begin{tabular}{|c|c|c|c|c|}
\hline No. & Wavelength (nm) & Osc. Strength & Symmetry & Major contributions \\
\hline 1 & 309.24 & 0.44 & Singlet-A & $\mathrm{HOMO} \rightarrow$ LUMO $(90 \%)$ \\
\hline 2 & 267.56 & 0.26 & Singlet-A & $\mathrm{H}-2 \rightarrow \mathrm{LUMO}(12 \%), \mathrm{HOMO} \rightarrow L+2(60 \%)$ \\
\hline 3 & 265.44 & 0.0032 & Singlet-A & H-6 $\rightarrow$ LUMO $(84 \%)$ \\
\hline
\end{tabular}


Fig. 2 Simulated UV-Visible spectrum of tucatinib using TDDFT CAM-B3LYP/cc-pVDZ

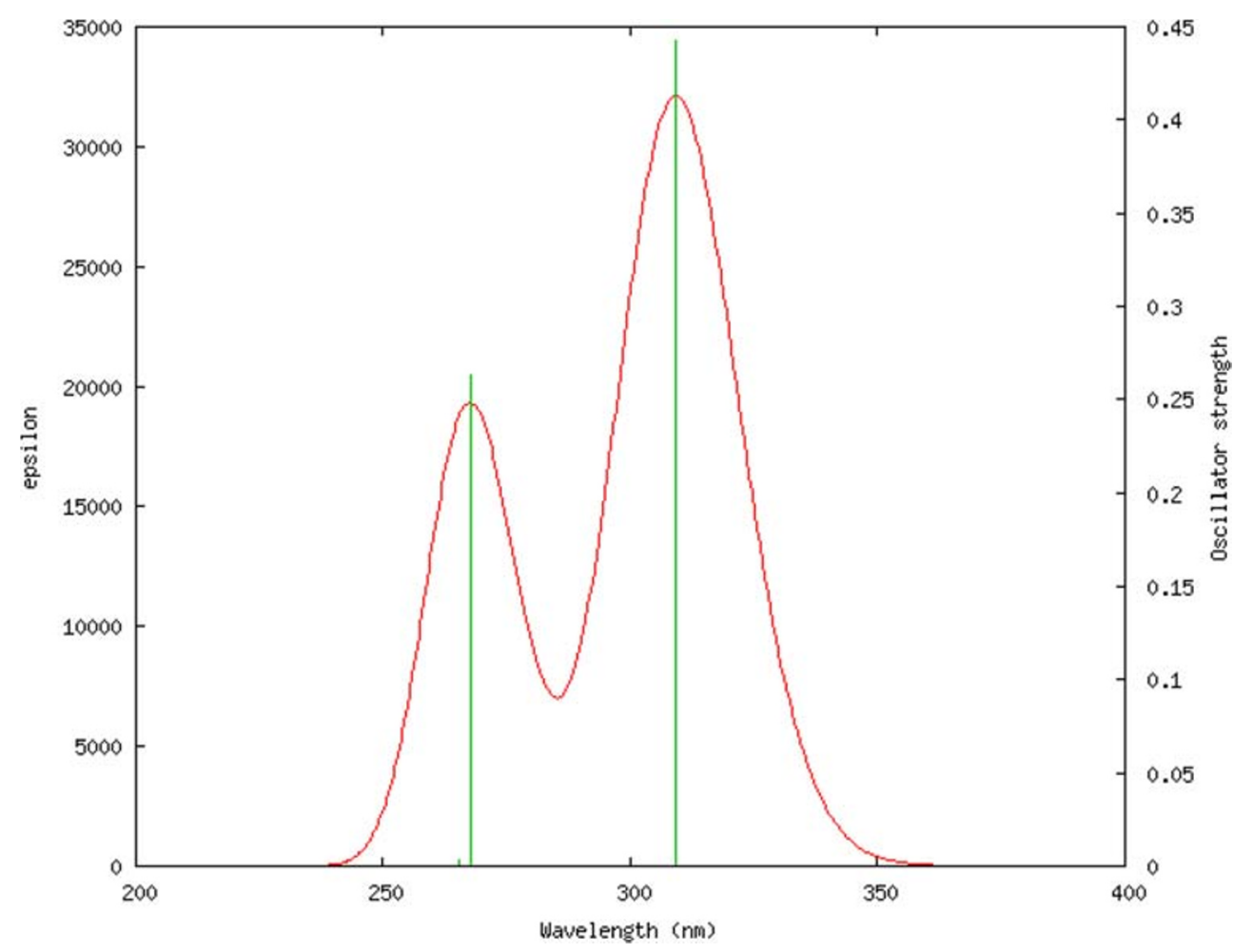

done using the NBO suite available within the Gaussian 09 software.

Table S1 shows the natural atomic orbital (NAO) occupancies for tucatinib. In general, the decreasing order of atomic orbitals by the occupancies are core orbital > valence orbital > Rydberg orbital. Table S1 shows the number of atomic orbitals, the symbol of atoms, number of atoms, angular momentum, type of atomic orbital, occupancies, and energy in a.u. unit Tucatinib having 624 nature atomic orbitals (NAOs), the oxygen atoms label numbers from 1 to 2 atoms nature atomic orbital numbers are 6,18 having py, and px angular momentum with atomic orbital type is valence $2 p$,

Fig. 3 Major and minor contributions for tucatinib

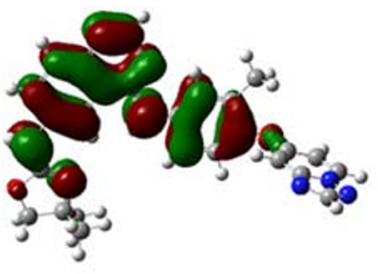

HOMO

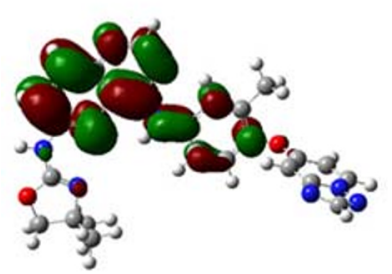

LUMO

occupancies are 1.40 and 1.11 , and energies are -0.37 and 037 a.u. respectively, the nitrogen atoms label numbers from 3 to 10 are having atomic orbital numbers are $34,46,60,78,90$, 102, 118 and 134 having py, px, px, pz, py, px, py and pz angular momentum with atomic orbital type is valence $2 \mathrm{p}$, occupancies are $1.31,1.41,1.36,1.24,1.25,1.28,1.29$ and 1.08 , and energies are $-0.20,-0.29,-0.28,-0.19,-0.20$, $-0.30,-0.18$ and -0.15 a.u. respectively, the carbon atoms label numbers from 11 to 36 are having atomic orbital numbers are 146, 160, 174, 190, 198, 216, 230, 242, 258, 272, 284, 298, 312, 326, 340, 354, 370, 382, 398, 412, 428, 442, 456, 466, 484 and 498 having py, py, py, pz, S, py, py, px, py,

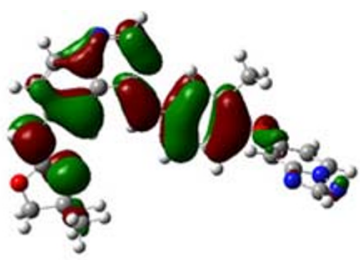

HOMO-2

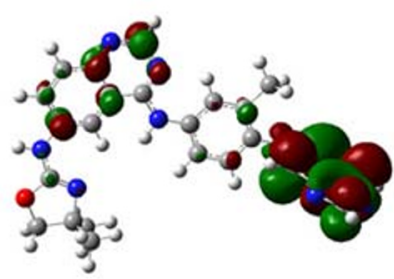

LUMO+2

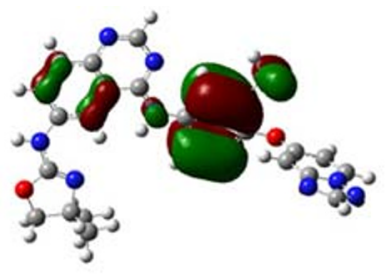

HOMO-7

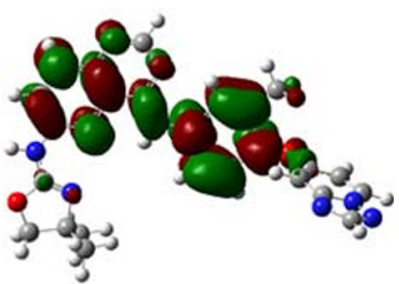

LUMO+4 
Table 4 Non-linear optics property for tucatinib

\begin{tabular}{lllll}
\hline Non-linear property & Tucatinib & Urea & $p$-nitro acetanilide & Comparison of tucatinib with urea and $P N A$ \\
\hline Dipole moment $(\mu)$ & $2.74 \mathrm{D}$ & $1.73 \mathrm{D}$ & $0.91 \mathrm{D}$ & 1.58 times urea and 3.01 times $P N A$ \\
Hyperpolarisability $(\beta)(\mathrm{esu})$ & $51.6 * 10^{-31}$ & $7.60 * 10^{-31}$ & $237.67 * 10^{-31}$ & 6.79 times urea and 0.21 times $P N A$ \\
Mean polarisability $\left(\alpha_{0}\right)$ & $373.08^{*} 10^{-23}$ & $24.30^{*} 10^{-23}$ & $113.86^{*} 10^{-23}$ & 15.5 times greater than urea and 3.27 times PNA \\
Anisotropy of the polarisability $(\Delta \alpha)(\mathrm{esu})$ & $897.38^{*} 10^{-23}$ & $0.85 * 10^{-23}$ & $5.29 * 10^{-23}$ & 1055 times greater than urea and 169 times PNA \\
Molar refractivity (MR) (esu) & 9412.26 & 613.31 & 2873.74 & 15.34 times greater than urea and 3.2 times PNA \\
\hline
\end{tabular}

py, px, px, px, px, px, px, py, px, py, py, pz, pz, pz, px, pz and $\mathrm{pz}$ angular momentum with atomic orbital type is valence $2 \mathrm{p}$, occupancies are $0.87,0.79,1.18,1.09,0.71,0.93,1.11,1.09$, $1.06,0.95,0.97,1.08,0.89,1.08,1.06,0.78,1.11,1.07,1.00$, $1.16,0.94,1.09,0.89,1.06,0.84$ and 1.03, and energies are $-0.15,-0.06,-0.06,-0.09,-0.08,-0.08,-0.03,-0.07$, $-0.06,-0.06,-0.01,-0.03,-0.05,-0.01,-0.05,-0.03$, $-0.01,-0.06,-0.05,-0.02,-0.08,-0.03,-0.07,-0.01$, $-0.07,-0.01$ and -0.02 respectively, and the hydrogen atoms label numbers from 37 to 60 are having atomic orbital numbers are 505, 510, 515, 520, 525, 530, 535, 540, 545, 550, 555, 560, 565, 570, 575, 580, 585, 590, 595, 600, 605, 610, 615 and 620 having S angular momentum with atomic orbital type is valence $1 \mathrm{~S}$, occupancies are $0.79,0.78,0.77,0.77$, $0.76,0.77,0.77,0.76,0.56,0.74,0.76,0.74,0.57,0.72$, $0.76,0.75,0.79,0.76,0.75,0.75,0.72,0.73,0.74$ and 0.78 , and energies are 0.07, 0.07, 0.08, 0.09, 0.09, 0.09, 0.08, 0.09, $0.11,0.11,0.07,0.10,0.12,0.13,0.08,0.09,0.09,0.10,0.09$, $0.09,0.11,0.09,0.08$ and 0.09 a.u. respectively.

Table S2 provides the summary of natural population charge analysis for tucatinib. Each atom having particular natural charges and population charges is core, valence and Rydberg populations. Tucatinib molecule's total natural charge is zero, and total natural populations in the core is 71.97, valence is 179.24 and the Rydberg population is 0.79 and the total population is 252.00. Table S3 shows the natural populations between natural minimal basis and natural Rydberg basis for tucatinib. Total core population is 71.97 out of 72 basis, which is more than 99.50 percentage; valence population is 179.24 out of 180 basis, which is more than 99.50 percentage; the natural minimal basis (NMB) is 251.21 out of 252 basis, which is more than 99.50 percentage; and natural Rydberg basis (RYB) is 0.79 out of 252 basis, which is below 0.50 percentage. Table $\mathrm{S} 4$ shows the electronic configurations for all the elements in tucatinib. Table S5 explains natural bond analysis by occupancy threshold energy for in tucatinib. For the cycles 1 and 2, having the same occupancy threshold energy 1.9 , Lewis occupancy is 238.24 , nonLewis occupancy is 13.76 and deviation is 0.63 . Table S6 shows the total Lewis and non-Lewis contributions for tucatinib. The contributions for core orbital are 71.97 out of 72 basis, which is more than 99.50 percentage, valence Lewis orbital is 173.56 out of 180 basis, which is 96.42 percentage and total Lewis contribution is 245.53 out of 252 basis, which is 97.43 percentage. The contribution of valence non-Lewis orbital is 5.92 out of 252 basis, which is 2.35 percentage, Rydberg non-Lewis orbital is 0.55 out of 252 basis, which is 0.22 percentage and total non-Lewis contribution is 6.47 out of 252 basis, which is 2.57 percentage.

Table S7 explains nature bond orbitals (NBOs) using second-order Perturbation theory analysis of Fock matrix in NBO Basis. This table explains various electrons transfers from donor natural atomic orbitals to acceptor natural atomic orbitals by labels and absorption energies. All these electron delocalisations lead to inherent stability of the molecule [73].

\section{Average localised ionisation energy for tucatinib}

The local $I(r)$ average energy of ionisation is the energy needed to remove an electron from point $r$ the system. The lowest values show the positions of the least tightly held electrons and therefore the chosen reaction sites by electrophiles or radicals [74-77]. The 2D representation of average localised ionisation energy (ALIE) of tucatinib is given in Fig. 4.

The colour greenish-blue is denoted delocalised electrons appearing in 4,4-dimethyloxazole, 4,4-dimethylozazolamin, quinazolin, quinazolinamin and triazolepyridin groups; these are giving the number of resonance structure and explain stability of tucatinib. The colour blue is denoted sigma or stable bonds occur in all the carbons, which are having protons. The colour red indicates multiple bonds; fortunately, there are no multiple bonds present in the tucatinib.

\section{Electron localised function for tucatinib}

This study explains the electronic structure for tucatinib. The higher value of electron localisation function is strongly localised and low value is strong delocalisation of electron in this molecule [78-80]. The electron localised function (ELF) for tucatinib is shown in Fig. 5. Tucatinib has the range between -16.34 and $16.34 \mathrm{Bohr}^{3}$, the probability value between 0.000 and 1.000, and the colour blue to red shown in Fig. 5.

The red in colour shows that high probability to strong חlocalised electrons occurs on the carbon, nitrogen and oxygen atoms core and lone-pair of electrons, and all the protons in the molecule. The blue in colour shows that high probability to 
Fig. 4 Average localised ionisation energy for tucatinib

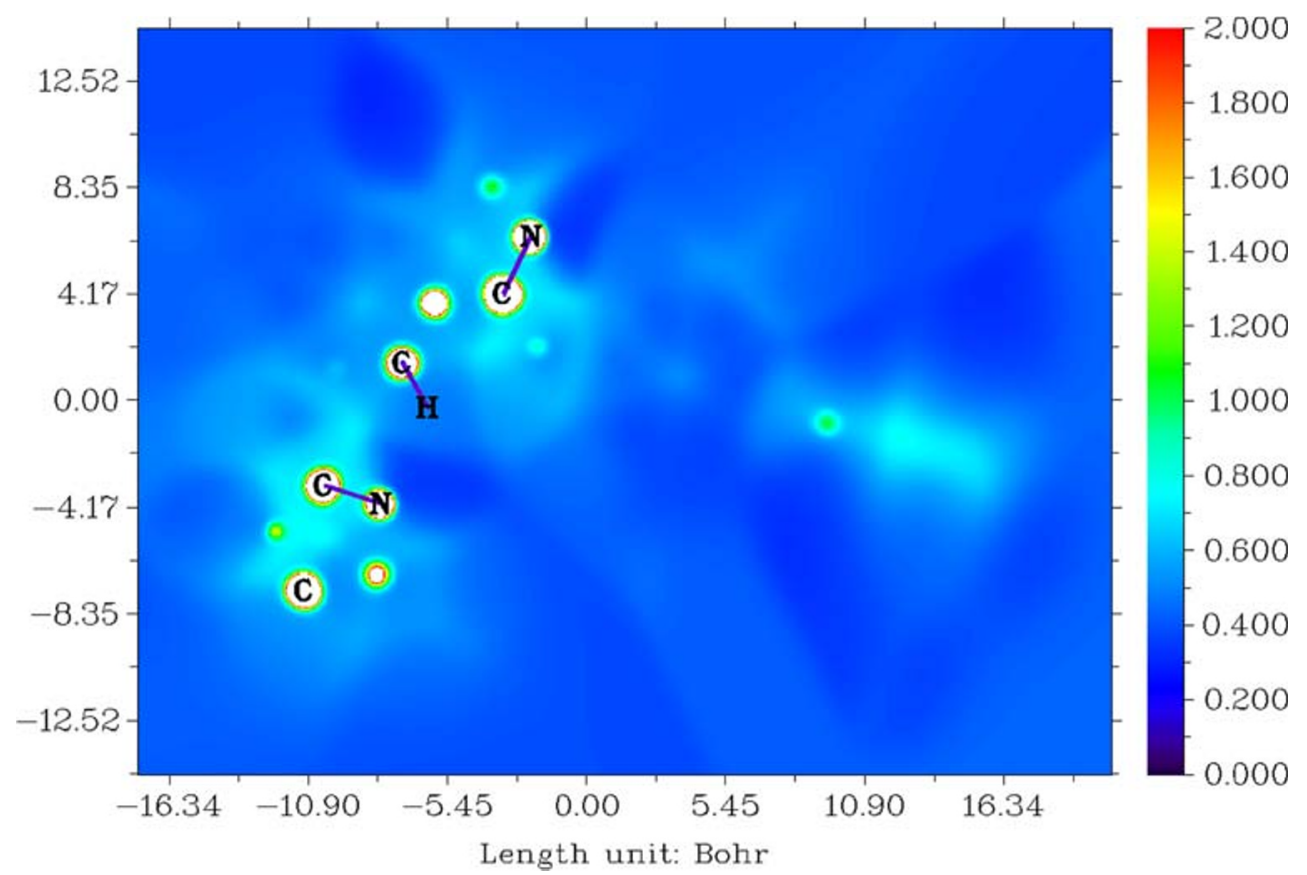

strong $\Pi$-delocalised electrons occurs on carbons and nitrogen atoms in 4,4-dimethyloxazolamin and quinolinamin rings, and 4,4-dimethyloxazolamin, quinolinamin and methylphenyl rings.

\section{Localised orbital locator for tucatinib}

Localised orbital locator (LOL) study explains the orbital locations for tucatinib [81, 82] and is represented in Fig. 6. The value ranges between -16.34 and $16.34 \mathrm{Bohr}^{3}$, values between 0.000 and 0.800 , and colour from blue to red shown in Fig. 6.

The colour red denotes strongly localised п-orbitals which occur between carbons and oxygens, carbons and nitrogens, and carbons and carbons in 4,4-dimethyloxazolamin, quinolinamin, methylphenyl and triazoxylpyridin groups. The colour blue denotes strong delocalised ח-orbitals which occurs in 4,4-dimethyloxazolamin, quinolinamin, methylphenyl, triazoxylpyridin rings and all the hydrogens in the whole molecule.
Fig. 5 Electron localised functions for tucatinib

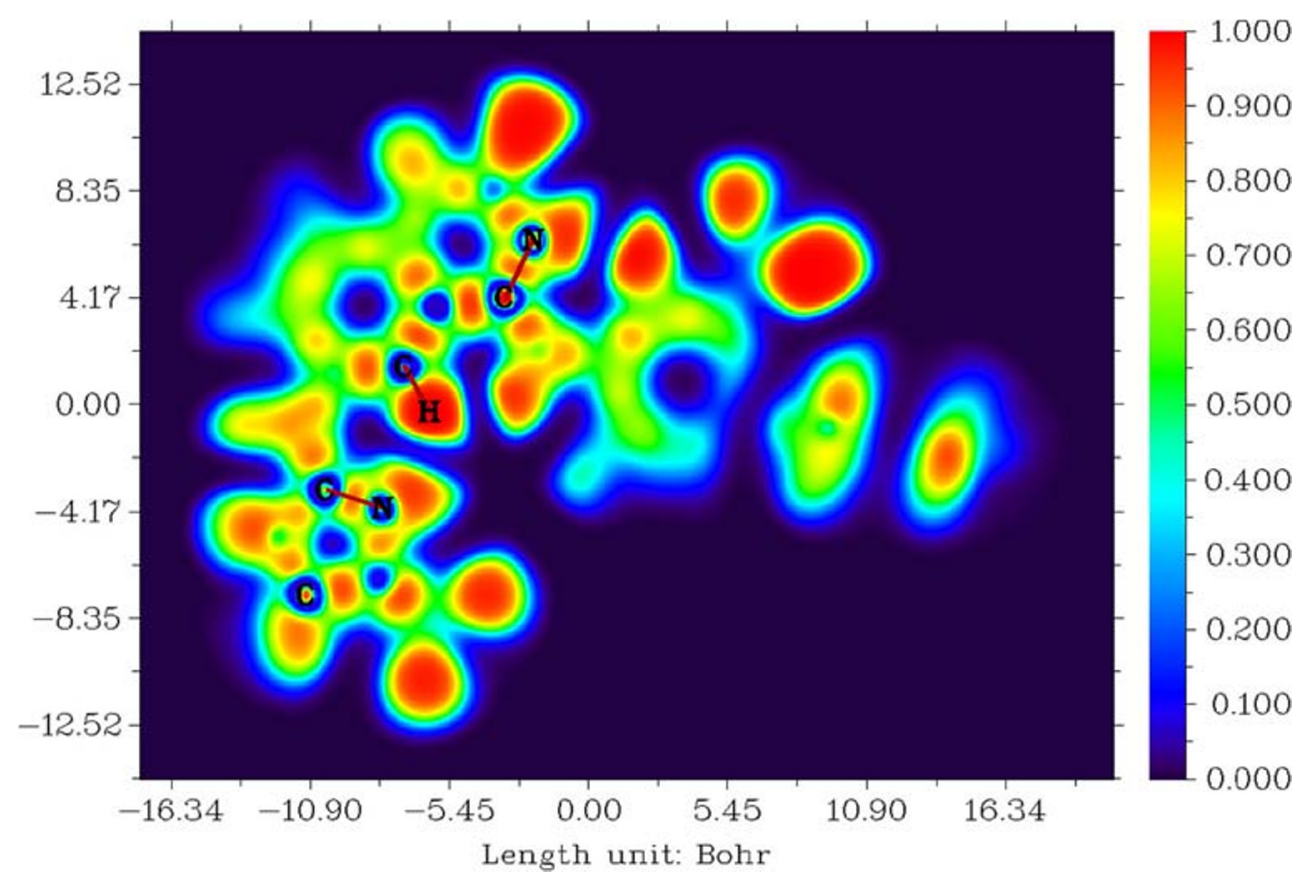




\section{Molecular electrostatic potentials (MESP) from elec- tronic charges for tucatinib}

The electrostatic potential $V(r)$ generated around a molecule by its nuclei and electrons which are treated as static charge distribution is a very useful property for studying and predicting molecular reactive actions [83-87]. The capacity has been especially useful as an indication of the positions or regions of the molecule to which the advancing electrophile is initially drawn, and has also been effectively extended to the analysis of associations requiring a certain optimal relative orientation of the reactants, such as between the product and its cellular receptor. Tucatinib molecule's MESP was generated using the data obtained in the previous calculation and is represented in Fig.7. Figure 7 shows those sites within the range between -16.26 and $16.26 \mathrm{Bohr}^{3}$, the numerical value from -0.100 to 0.100 and the colour from blue to red.

The colour blue on all the nitrogen atoms in amin-oxazole and amin-quinazolin groups is electron-rich sites, and therefore electrophiles can easily attack these sites. The colour red on all the carbons which are having protons in 4,4-dimethylozalol, quinazolin, 2-methylphenolat and triazolepyridine groups is electron-poor sites, and therefore nucleophiles can easily attack these sites.

\section{Molecular electrostatic potentials (MESP) from nucle- ar charges for tucatinib}

The electrostatic potentials from nuclear charges [85, 87] for tucatinib are shown in Fig. 8. Tucatinib has the range between -15.88 and 17.67 $\mathrm{Bohr}^{3}$, values between 0.000 and 0.800, and colour from blue to red shown in Fig. 8 .
The colour red denotes negative electrostatic potentials between the range 47.000 and 50.000 and shows strong attraction between protons and nuclei core and lone-pair of electrons in carbons, nitrogens and oxygens in 4,4dimethyloxazolamin, quinazolinamin and triazoxylpyridin groups. The colour blue denotes positive electrostatic potentials between the range 15.000 and 23.000 and shows strong repulsions between protons and nuclei in all the hydrogens in the whole molecule.

\section{Reduced density gradients (RDG) for tucatinib}

The reduced density gradient is directly proportional to the electronic density of the molecule. Which means a small reduced density gradient is low electronic density [88-92]. Figure 9 shows the reduced density gradient for tucatinib. Tucatinib has the range between -14.88 and $16.34 \mathrm{Bohr}^{3}$, values between 0.000 and 1.000 , and colour from blue to red shown in Fig. 9.

The colour red range between 0.800 and 1.000 shows the most probability of the reduced density gradients which occur in higher molecular weight elements which are oxygens, nitrogens and carbons in 4,4-dimethyloxazolamin, quinolinamin, methylphenyl and triazoxylpyridin groups.

\section{Local information entropy (LIE) for tucatinib}

This study explains the stability of the molecule. Entropy is a feature of probability distributions and can take to be a qualification of uncertainty. The high value of local information entropy is directionally proportional to the uncertainty of electrons in spatial distribution [93, 94]. Figure 10 shows local

Fig. 6 Localised orbital location for tucatinib

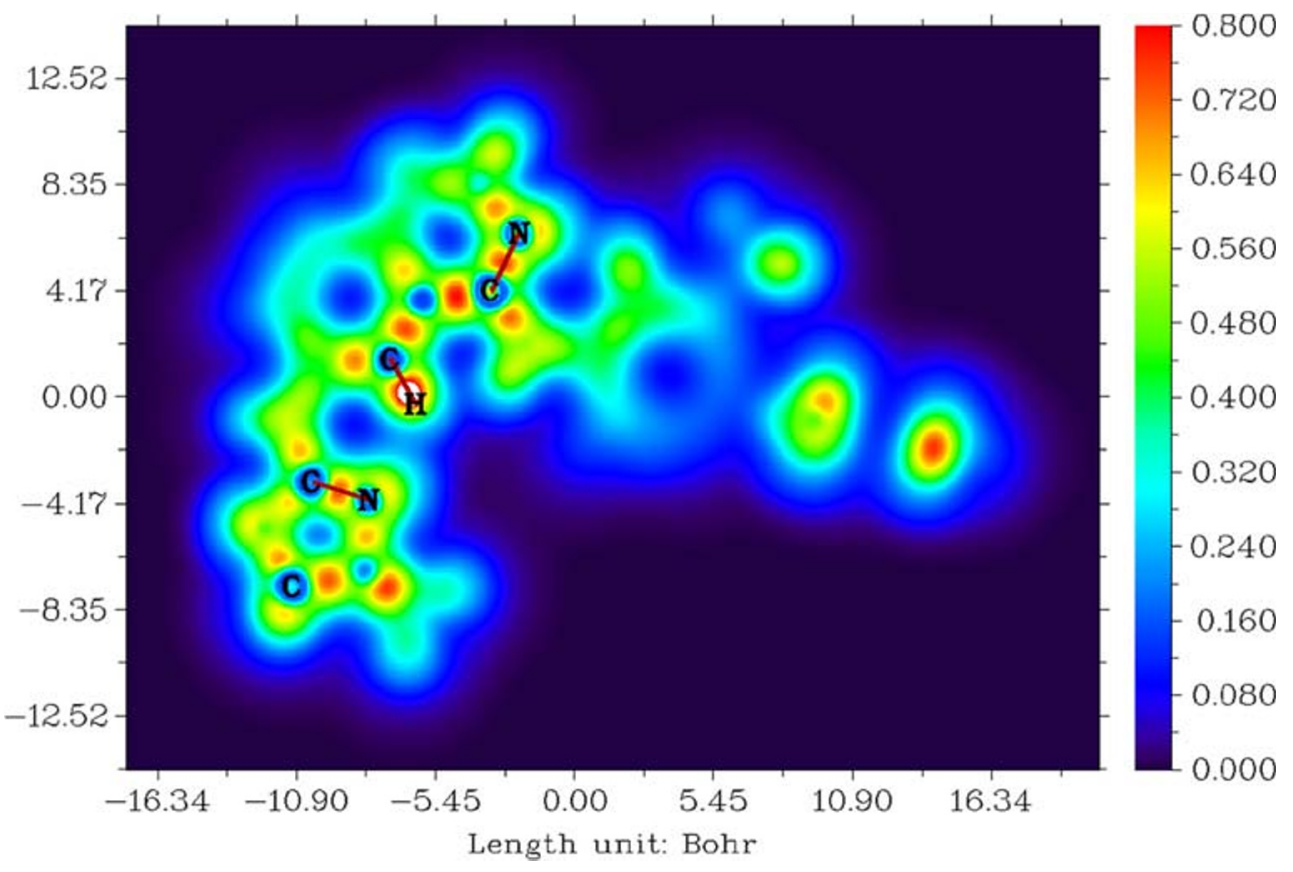


Fig. 7 Molecular electrostatic potentials for tucatinib

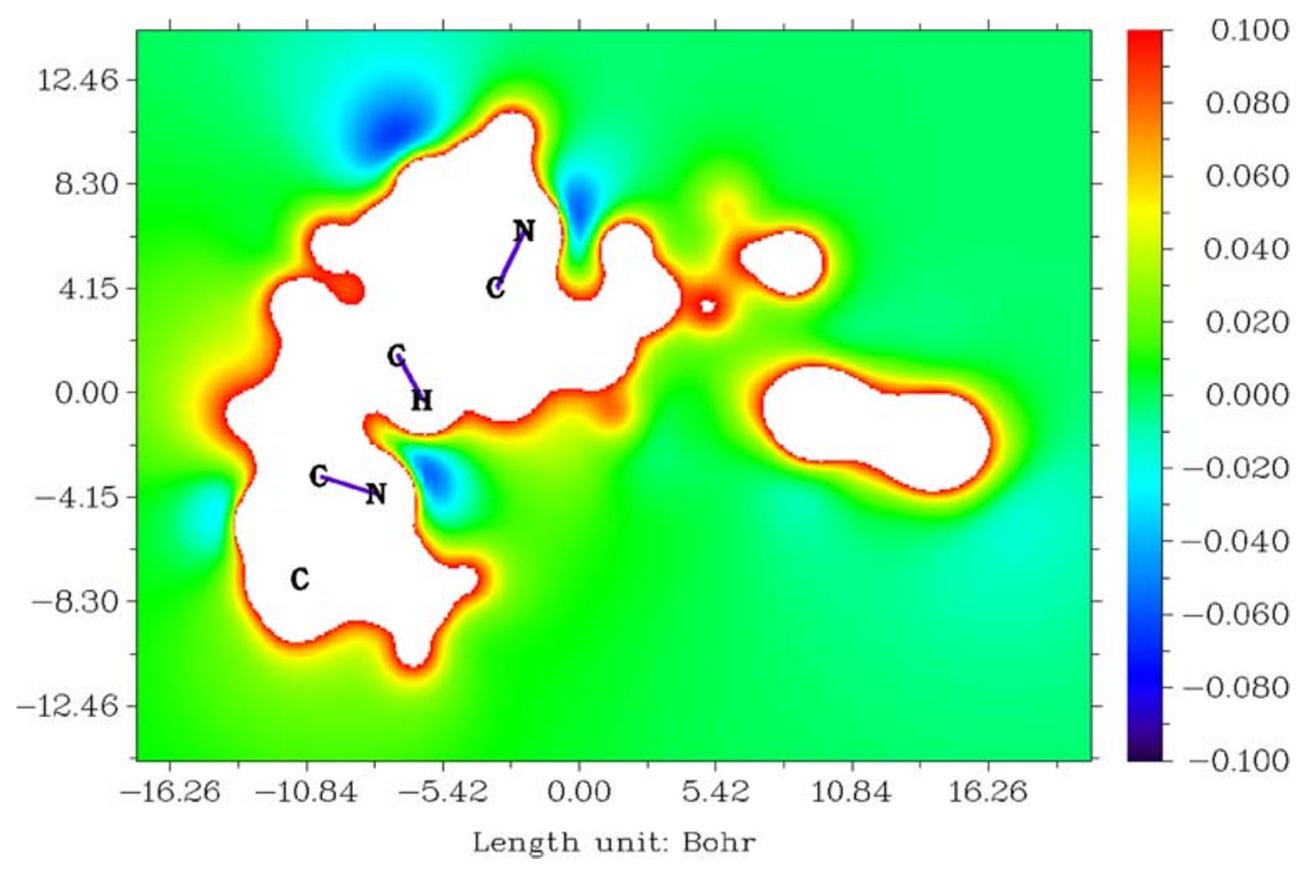

information entropy for tucatinib. Tucatinib has the range between -16.34 and 16.34 $\mathrm{Bohr}^{3}$, values between 0.000 and 0.100 , and colour from blue to red shown in Fig. 10.

The colour blue shows the entropy value between 0.000 and 0.015 which denotes low uncertainty regions in 4,4dimethyloxazolamin, quinolinamin, methylphenyl and triazoxylpyridin groups. The colour bluish-green shows the moderated entropy values between 0.035 and 0.045 which denotes moderated uncertainty of the elements which are carbons, nitrogens and oxygens in 4,4-dimethyloxazolamin and quinolinamin groups.

\section{Non-covalent interactions ( $\mathrm{NCl}$ ) for tucatinib}

A non-covalent interaction differs from a covalent bond by not involving the sharing of electrons but involving more dispersed variations of electromagnetic interactions between molecules or within a molecule. The threedimensional arrangement of large molecules, such as protein and nucleic acids, is important to non-covalent interactions. Additionally, they are also involved in many biological processes where large molecules bind to each other specifically but transiently. These
Fig. 8 Molecular electrostatic potentials from nuclear charges for tucatinib

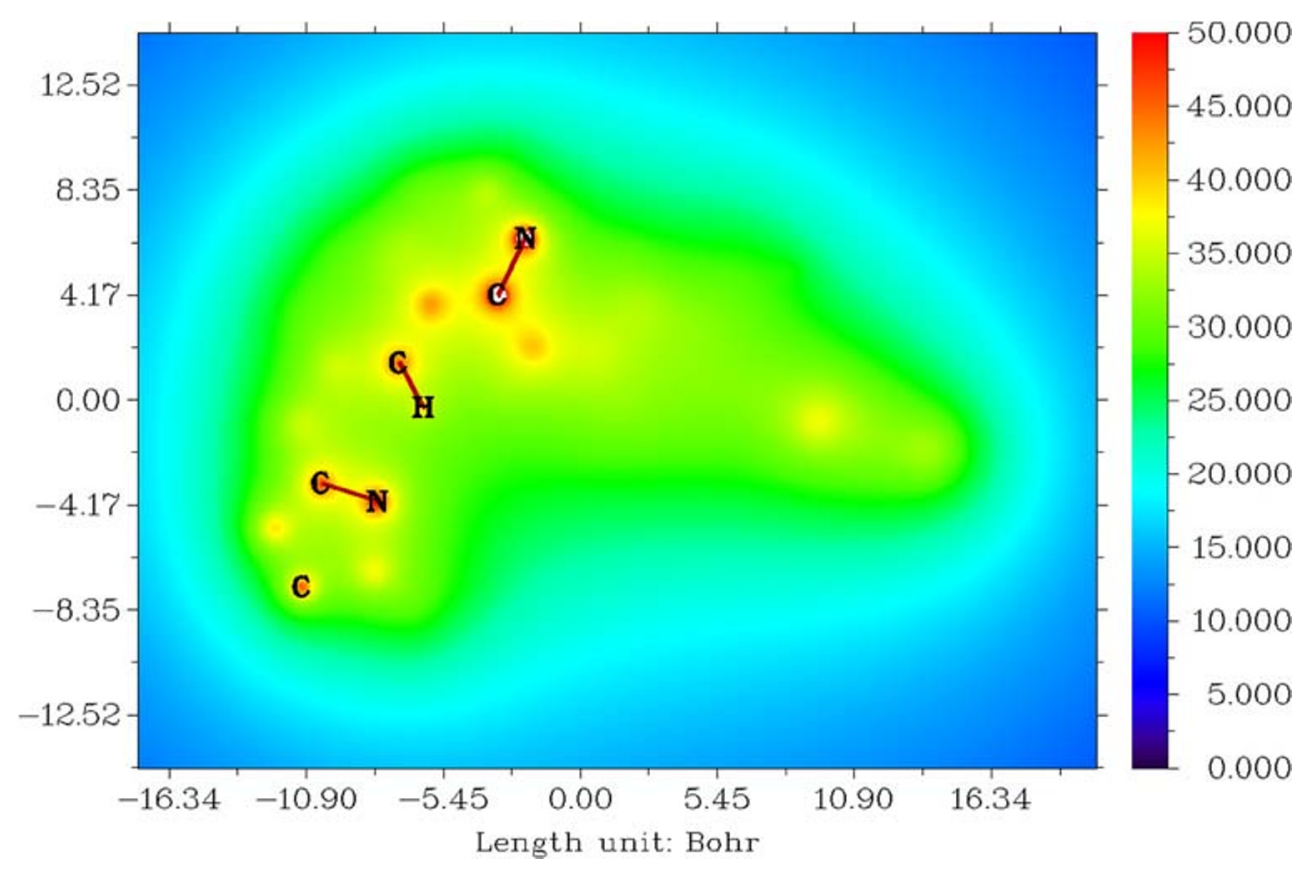


Fig. 9 Reduced density gradient for tucatinib

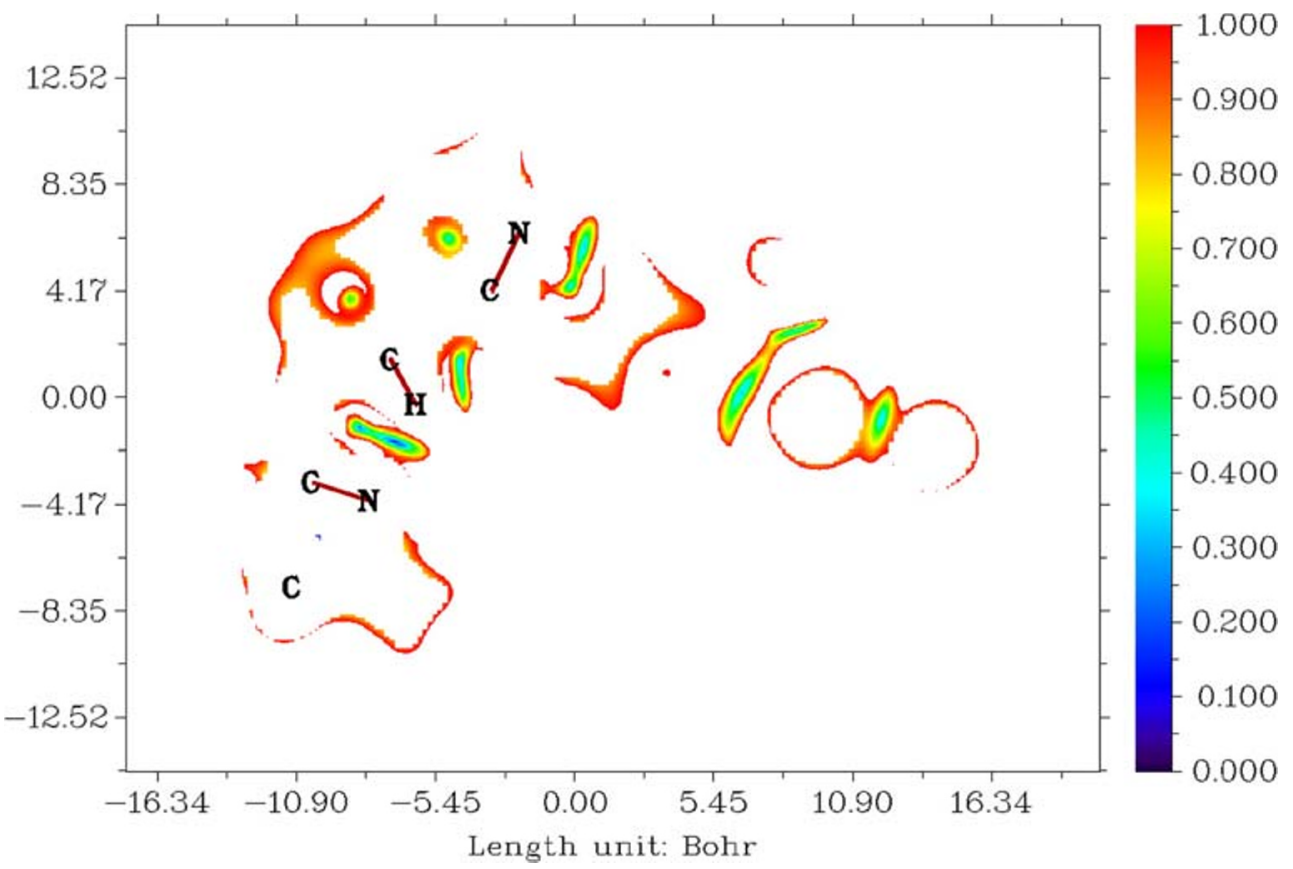

interactions also have a strong impact on drug design, crystallinity and material design, self-assembly and the design of synthesis of tailor-made organic molecules $[89,95]$. The non-covalent interactions for tucatinib are shown in Fig. 11.

This study explains the non-covalent bonds which occur in the molecule. Figure 11 shows the non-covalent bonds which are hydrogen-bond, van der Waals and steric force type of bonds which occurs in the tucatinib; a graph plotted energy against reduced density gradient.
The hydrogen bonds appear between the range -0.020 and -0.005 a.u. from secondary amin-nitrogen attached in 4,4dimethyloxazol to hydrogens in methyl in 4,4-dimethyloxazol and quinazolin groups, and from secondary amin-nitrogen attached in quinazolin to hydrogens in quinazolin and 2methylphenoate groups, the van der Waals force between the range -0.005 and 0.003 a.u. from oxygen in 2methylphenolat to hydrogens in methyl in 2-methylphenoate and triazolepyridin groups, and steric force between the range 0.004 and 0.050 a.u. within the rings for 4,4-dimethyloxazol,

Fig. 10 Local information entropy for tucatinib

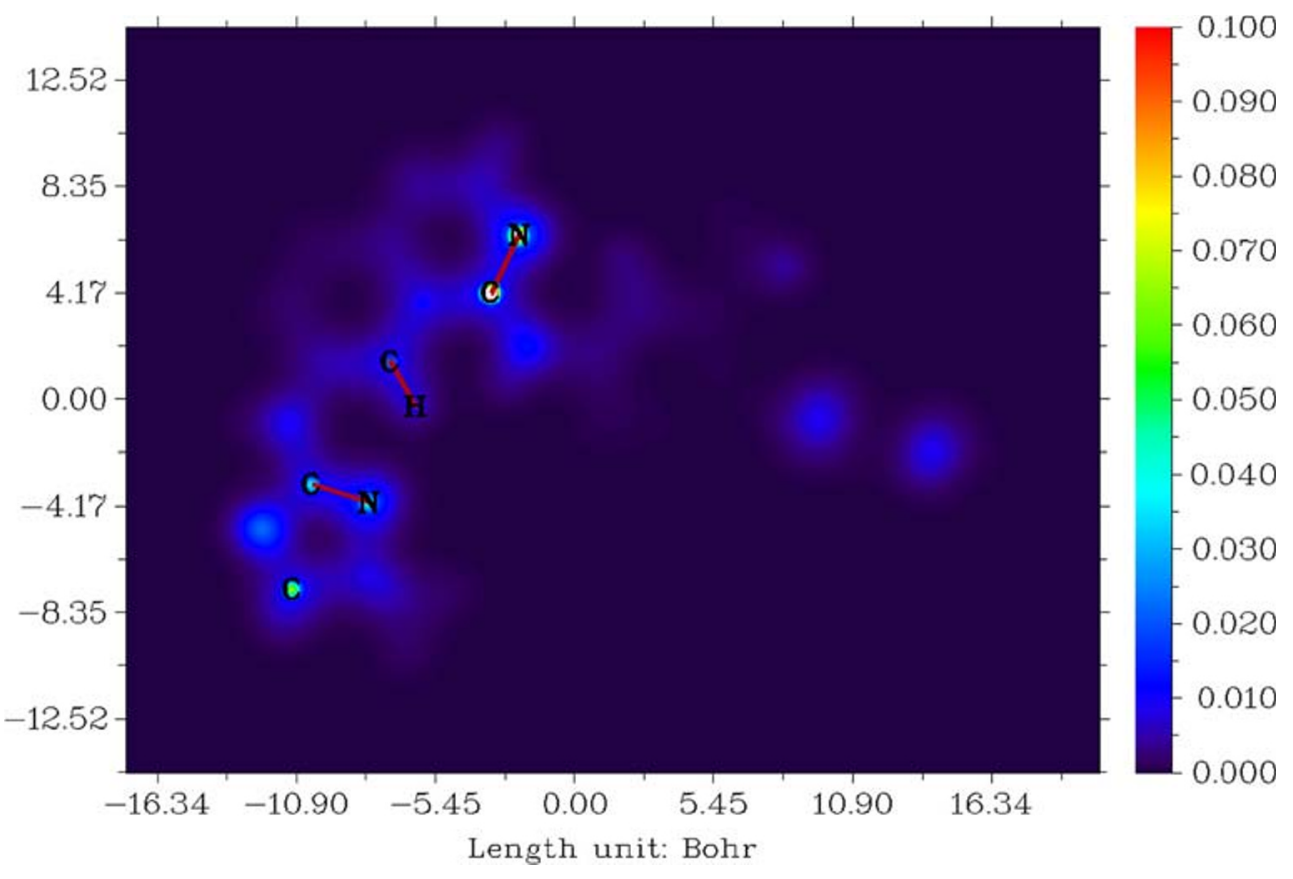


quinazolin, 2-methylphenoate and triazolepyridin groups, and between 4,4-dimethyloxazol and quinazol, quinalolin and 2methylphenolat, and 2-methylphenolat and triazolepyridin groups.

\section{Molecular docking study for tricatinib}

Scientists around the globe are looking medicines for managing the COVID pandemic. It is always better to reroute the existing drugs for this pandemic as it could save lot of precious time for new drug discovery. We also thought in this direction and checked the activity of this drug against known COVID proteins. Molecular docking can be used as a tool to screen the biological activity of a compound [96, 97]. Molecular docking explains the structure relative activity of tucatinib against coronovirus2 proteins (PDB IDs: 6M03 [98], 6W63 [99], 6LZG [100] and 6LU7 [99]) deposited in the RSC database [30].

Table 5 shows the docking result from SwissDock server, tucatinib with coronovirus 2 proteins are 6LU7, 6W63, 6M03 and 6LZG having full fitness values are $-1276.22,-1238.58$, -1243.04 and $-3497.47 \mathrm{kcal} / \mathrm{mol}$ respectively, and estimated $\Delta G$ are $-9.42,-8.94,-8.45$ and $-8.32 \mathrm{kcal} / \mathrm{mol}$ respectively. The interactions tucatinib with $6 \mathrm{LU} 7$ having greater interfull fitness, intrafull fitness, $\Delta G$ ligand solvent nonpolar and $\Delta G$ van der Waals force energies than other compared proteins, and protein 6LZG having greater energy, simple fitness, solvent full fitness, surface full fitness, $\Delta G$ complex solvent polar, $\Delta G$ complex solvent nonpolar, $\Delta G$ protein solvent polar, $\Delta G$ protein solvent non-polar and $\Delta G$ ligand solvent polar energies than other compared proteins.

The results from the docking of tucatinib and coronovirus2 proteins with PDB IDs: 6LU7, 6W63, 6M03 and 6LZG using PatchDock gives the docking score values as 5640, 5594, 5470 and 6182 respectively. The interacting areas are 706.70, 74,840, 573.90 and $716.40 \AA^{2}$ respectively; minimum atomic contact energies are $-348.62,-416.91,-151.45$ and $-128.30 \mathrm{kcal} / \mathrm{mol}$ respectively; and molecule solvent accessibilities are $3158.43,2819.61,2753.54$ and $3748.54 \AA^{2}$ respectively fpr different proteins used. Figure 12 shows the skeletal structure and residues with labels of interactions between tucatinib with coronovirus 2 proteins, and Table S8 explains the coronovirus 2 protein labels, name, hydrophobicity, $\mathrm{pKa}$, average isotropic displacement, secondary structure, residue solvent accessibility, sidechain solvent accessibility, percent solvent accessibility and percent sidechain solvent accessibility values.

Table S9 explains the non-covalent bonds which occur between tucatinib with coronovirus 2 proteins are favourable non-bond, unfavourable non-bond and unsatisfied bond within tucatinib interacting with coronovirus 2 proteins. Table S8 explains the non-covalent bonds are hydrophobicity, hydrophilicity, neutral, acidic and basic group label interactions between tucatinib with coronovirus 2 proteins.

Figure S1, Table S2 and Table 4 explain the water-resistant as well as called hydrophobic interactions between tucatinib with coronovirus 2 proteins. Figure S2, Table S9 and Table 6 show water-loving groups of interactions between tucatinib with coronovirus 2 proteins. Table S9 and Table 6 with
Fig. 11 Non-covalent interactions for tucatinib

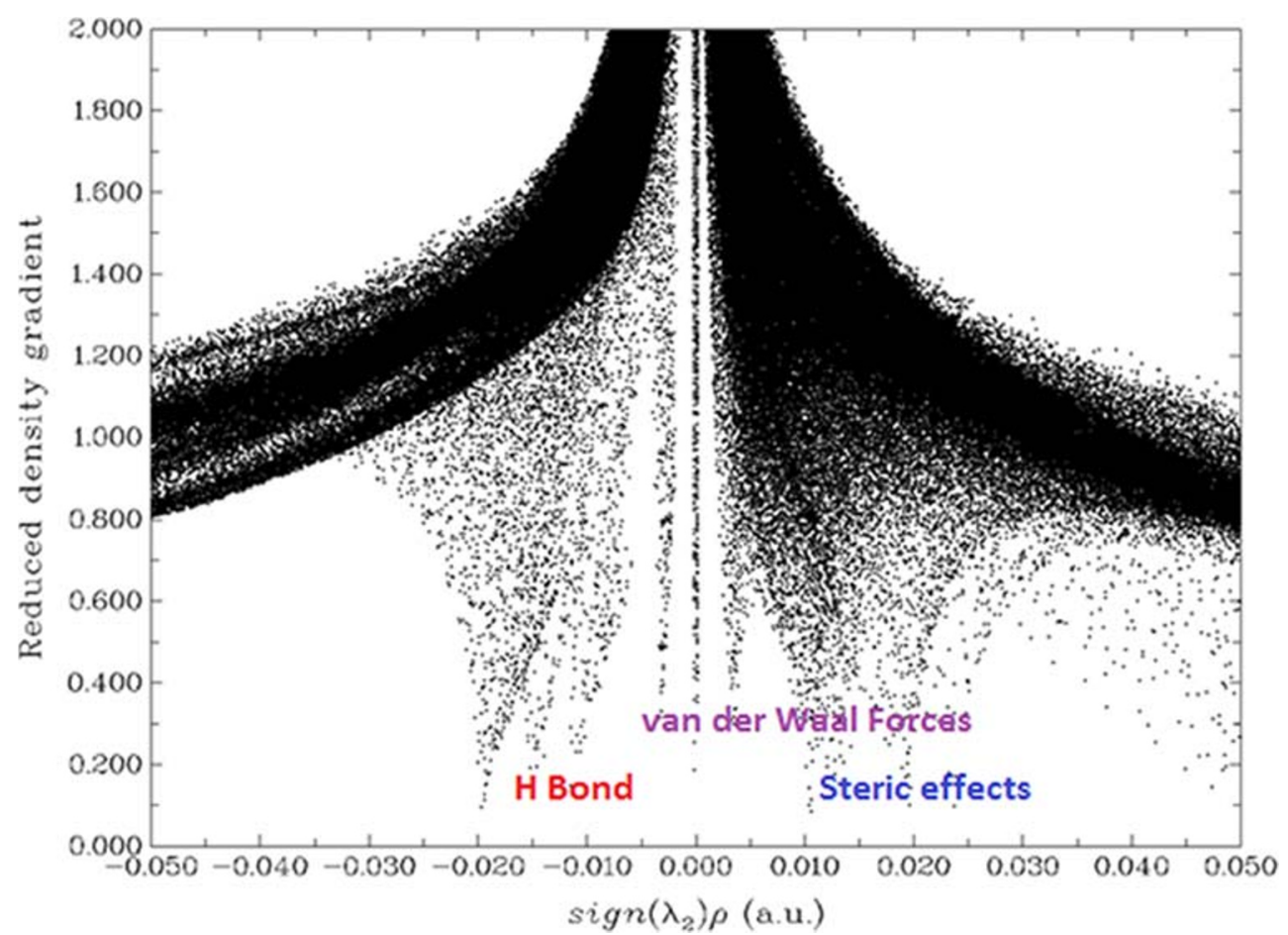


Table 5 Docking result for tucatinib with coronovirus2 proteins

\begin{tabular}{lllll}
\hline Parameters & 6 LU7 & 6 W63 & $6 \mathrm{M} 03$ & $6 \mathrm{LGZ}$ \\
\hline Energy & $58.0421 \mathrm{kcal} / \mathrm{mol}$ & $54.9743 \mathrm{kcal} / \mathrm{mol}$ & $60.3017 \mathrm{kcal} / \mathrm{mol}$ & $61.3409 \mathrm{kcal} / \mathrm{mol}$ \\
Simple fitness & $58.0421 \mathrm{kcal} / \mathrm{mol}$ & $54.9743 \mathrm{kcal} / \mathrm{mol}$ & $60.3017 \mathrm{kcal} / \mathrm{mol}$ & $61.3409 \mathrm{kcal} / \mathrm{mol}$ \\
Full fitness & $-1276.2 \mathrm{kcal} / \mathrm{mol}$ & $-1238.6 \mathrm{kcal} / \mathrm{mol}$ & $-1243 \mathrm{kcal} / \mathrm{mol}$ & $-3497.5 \mathrm{kcal} / \mathrm{mol}$ \\
Interfull fitness & $-68.14 \mathrm{kcal} / \mathrm{mol}$ & $-58.674 \mathrm{kcal} / \mathrm{mol}$ & $-59.893 \mathrm{kcal} / \mathrm{mol}$ & $-62.734 \mathrm{kcal} / \mathrm{mol}$ \\
Intrafull fitness & $11.7314 \mathrm{kcal} / \mathrm{mol}$ & $5.60706 \mathrm{kcal} / \mathrm{mol}$ & $9.84711 \mathrm{kcal} / \mathrm{mol}$ & $9.53814 \mathrm{kcal} / \mathrm{mol}$ \\
Solvent full fitness & $-1439 \mathrm{kcal} / \mathrm{mol}$ & $-1405.4 \mathrm{kcal} / \mathrm{mol}$ & $-1413.6 \mathrm{kcal} / \mathrm{mol}$ & $-3978 \mathrm{kcal} / \mathrm{mol}$ \\
Surface full fitness & $219.201 \mathrm{kcal} / \mathrm{mol}$ & $219.847 \mathrm{kcal} / \mathrm{mol}$ & $220.597 \mathrm{kcal} / \mathrm{mol}$ & $533.718 \mathrm{kcal} / \mathrm{mol}$ \\
Extra full fitness & $0 \mathrm{kcal} / \mathrm{mol}$ & $0 \mathrm{kcal} / \mathrm{mol}$ & $0 \mathrm{kcal} / \mathrm{mol}$ & $0 \mathrm{kcal} / \mathrm{mol}$ \\
$\Delta G$ complex solvent polar & $-1439 \mathrm{kcal} / \mathrm{mol}$ & $-1405.4 \mathrm{kcal} / \mathrm{mol}$ & $-1413.6 \mathrm{kcal} / \mathrm{mol}$ & $-3978 \mathrm{kcal} / \mathrm{mol}$ \\
$\Delta G$ complex solvent non-polar & $219.201 \mathrm{kcal} / \mathrm{mol}$ & $219.847 \mathrm{kcal} / \mathrm{mol}$ & $220.597 \mathrm{kcal} / \mathrm{mol}$ & $533.718 \mathrm{kcal} / \mathrm{mol}$ \\
$\Delta G$ protein solvent polar & $-1411.4 \mathrm{kcal} / \mathrm{mol}$ & $-1372.1 \mathrm{kcal} / \mathrm{mol}$ & $-1385.7 \mathrm{kcal} / \mathrm{mol}$ & $-3956.8 \mathrm{kcal} / \mathrm{mol}$ \\
$\Delta G$ protein solvent non-polar & $221.095 \mathrm{kcal} / \mathrm{mol}$ & $222.123 \mathrm{kcal} / \mathrm{mol}$ & $221.3 \mathrm{kcal} / \mathrm{mol}$ & $533.989 \mathrm{kcal} / \mathrm{mol}$ \\
$\Delta G$ ligand solvent polar & $-62.539 \mathrm{kcal} / \mathrm{mol}$ & $-61.961 \mathrm{kcal} / \mathrm{mol}$ & $-64.017 \mathrm{kcal} / \mathrm{mol}$ & $-63.078 \mathrm{kcal} / \mathrm{mol}$ \\
$\Delta G$ ligand solvent non-polar & $10.0198 \mathrm{kcal} / \mathrm{mol}$ & $9.94932 \mathrm{kcal} / \mathrm{mol}$ & $9.90626 \mathrm{kcal} / \mathrm{mol}$ & $9.90859 \mathrm{kcal} / \mathrm{mol}$ \\
$\Delta G$ van der Waals force & $-68.14 \mathrm{kcal} / \mathrm{mol}$ & $-58.674 \mathrm{kcal} / \mathrm{mol}$ & $-59.893 \mathrm{kcal} / \mathrm{mol}$ & $-62.734 \mathrm{kcal} / \mathrm{mol}$ \\
$\Delta G$ electric force & $0 \mathrm{kcal} / \mathrm{mol}$ & $0 \mathrm{kcal} / \mathrm{mol}$ & $0 \mathrm{kcal} / \mathrm{mol}$ & $-8.4504 \mathrm{kcal} / \mathrm{mol}$
\end{tabular}

Fig. S3, S4 and S5 explain the neutral, acidic and basic groups of interactions between tucatinib with coronovirus 2 proteins respectively.

\section{Conclusions}

Tucatinib molecule having good HOMO-LUMO values, which show good chemical parameters energy gap, ionisation energy, electron affinity, global hardness, global softness, chemical potentials, electronegativity, electrophilicity index and nucleophilicity index. From the UV-Visible spectrum result, tucatinib has shown absorption peaks at 309.1468 and $267.5687 \mathrm{~nm}$ with 0.4431 and 0.2633 oscillator strengths.
From the NLO property of tucatinib, the dipole moment is 2.1797 times greater than urea and 7.9092 times greater than $p$-nitro acetanilide, hyperpolarisability is 10.9881 times greater than urea and 1.2032 times greater than $p$-nitro acetanilide, mean polarisability is 15.3529 times greater than urea and 3.0367 times greater than $p$-nitro acetanilide, the anisotropy of the polarisability is 16.9187 times greater than urea and 2.5999 times greater than $p$-nitro acetanilide, and molar refractivity (MR) is 15.3494 times greater than urea and 3.0360 times greater than $p$-nitro acetanilide. The NBO result explains the molecular bonding property of tucatinib having suitable occupancies with energies. The reaction site properties were electrostatic potentials, average localised ionisation energy and non-covalent interactions mostly occur on 4,4-
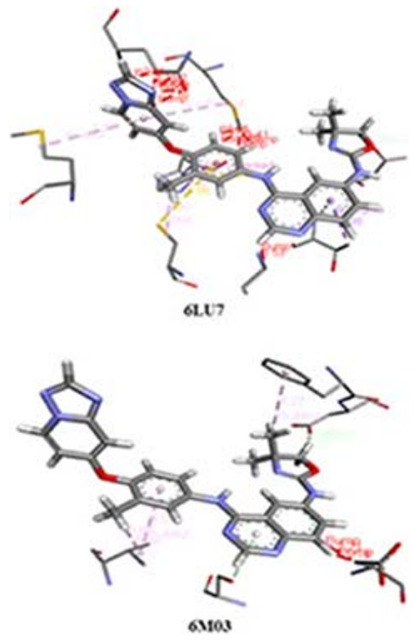

Fig. 12 Skeletal structure of interactions between tucatinib and coronovirus 2 proteins
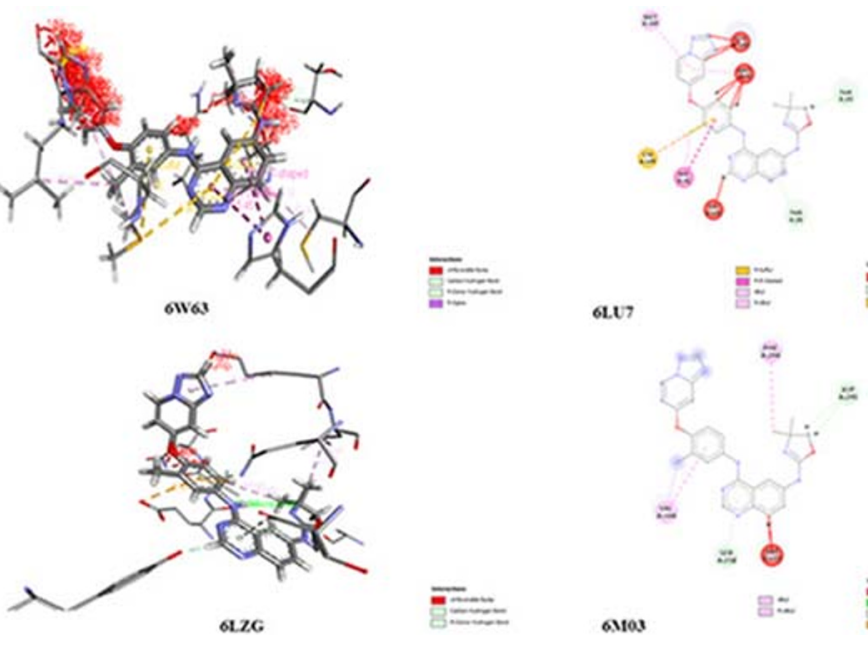
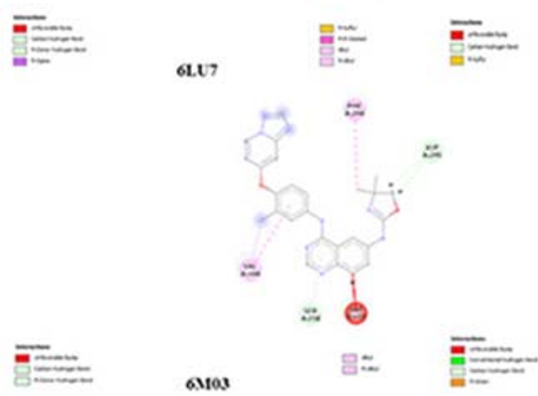

anos

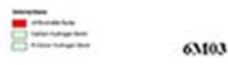

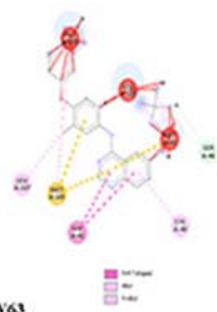

6was

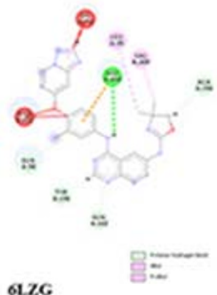


Table 6 Non-bond interactions label between coronovirus2 protein residues and tucatinib

\begin{tabular}{|c|c|c|}
\hline $\begin{array}{l}\text { Non-bond } \\
\text { interactions }\end{array}$ & $\begin{array}{l}\text { Name of the coronovirus } 2 \\
\text { proteins }\end{array}$ & Labels of the coronovirus 2 proteins \\
\hline \multirow[t]{4}{*}{ Hydrophobicity } & 6LU7 & $\begin{array}{l}\text { THR A:24, THR A:26, HIS A:41, CYS A:44, MET A:49, GLY A:143, CYS A:145, MET A:165 and } \\
\text { GLN A:189 }\end{array}$ \\
\hline & 6W63 & $\begin{array}{l}\text { HIS A:41, CYS A:44, SER A:46, MET A:49, LEU A:50, MET A:165, LEU A:167, PRO A:168, GLN } \\
\text { A:189 and ALA A:191 }\end{array}$ \\
\hline & $6 \mathrm{M} 03$ & $\begin{array}{l}\text { PHE A:8, VAL A:104, ILE A:106, PHE A:112, ILE A:152, ASP A:153, SER A:158, PHE A:294, ASP } \\
\text { A:295 and PHE A:305 }\end{array}$ \\
\hline & $6 \mathrm{LZG}$ & $\begin{array}{l}\text { LEU A:85, LYS A:94, LEU A:95, GLN A:98, GLN A:102, TYR A:196, GLU A:208, VAL A:209, ASN } \\
\text { A:210 and ALA A:396 }\end{array}$ \\
\hline \multirow[t]{4}{*}{ Hydrophilicity } & 6LU7 & $\begin{array}{l}\text { THR A:24, THR A:26, HIS A:41, ASN A:142, GLY A:143, HIS A:164, ASP A:187, ARG A:188 and } \\
\text { GLN A:189 }\end{array}$ \\
\hline & 6W63 & HIS A:41, SER A:46, GLU A:166, PRO A:168, ASP A:187, ARG A:188, GLN A:189 and GLN A:192 \\
\hline & $6 \mathrm{M} 03$ & $\begin{array}{l}\text { LYS A:102, ARG A:105, GLN A:107, GLN A:110, GLN A:127, ASN A:151, ASP A:153, SER A:158 } \\
\text { ASP A:295 and ARG A:298 }\end{array}$ \\
\hline & $6 \mathrm{LZG}$ & $\begin{array}{l}\text { LYS A:94, GLN A:98, GLN A:102, TYR A:196, ASP A:206, GLU A:208, ASN A:210, ARG A:219, } \\
\text { ASN A:397, LYS A:562 and GLU A:564 }\end{array}$ \\
\hline \multirow[t]{4}{*}{ Neutral groups } & 6LU7 & THR A:24, THR A:25, THR A:26, THR A:45, SER A:46, GLY A:143 and SER A:144 \\
\hline & 6W63 & THR A:45, SER A:46, PRO A:168, THR A:169, GLY A:170 and THR A:190 \\
\hline & $6 \mathrm{M} 03$ & THR A:111, SER A:158 and THR A:292 \\
\hline & $6 \mathrm{LZG}$ & TYR A:196, GLY A:205, PRO A:565 and TRP A:566 \\
\hline \multirow[t]{4}{*}{ Acidic groups } & 6LU7 & ASP A:187 \\
\hline & 6W63 & GLU A:166 and ASP A:187 \\
\hline & $6 \mathrm{M} 03$ & ASP A:153 and ASP A:295 \\
\hline & $6 \mathrm{LZG}$ & ASP A:206, GLU A:208 and GLU A:564 \\
\hline \multirow[t]{4}{*}{ Basic groups } & 6LU7 & HIS A:41, HIS A:164 and ARG A:188 \\
\hline & 6W63 & HIS A:41 and ARG A:188 \\
\hline & $6 \mathrm{M} 03$ & LYS A:102, ARG A:105 and ARG A:298 \\
\hline & $6 \mathrm{LZG}$ & LYS A:94, ARG A:219 and LYS A:562 \\
\hline
\end{tabular}

dimethyloxazol, amin- in 4,4-dimethyloxazole, quinazolin, amin- in quinazoline, 2-methylphenolat and triazolepyridin groups in tucatinib. From the molecular docking result, it explains types of interactions, hydrophilicity, and hydrophobicity, acidic, basic and neutral group residues of referred coronovirus2 proteins (6LU7, 6W63, 6M03 and 6LZG) with tucatinib.

Supplementary Information The online version contains supplementary material available at https://doi.org/10.1007/s00894-020-04603-1.

Authors' contributions Ali Alsalme: Problem selection, writing and data analysis.

T. Pooventhiran: Simulations, analysis, manuscript first draft.

Nabil Al-Zaqri: Methods, project management, result analysis, manuscript editing.

D. Jagadeeswara Rao: Result analysis, manuscript editing.

Siriki Srinivasa Rao: Data analysis, writing.

Renjith Thomas: Conceiving problem, project management, software, simulations, supervision.

Funding This work was financially supported by Researchers Supporting Project number (RSP-2020/78), King Saud University, Riyadh, Saudi Arabia.
Data availability Related data are provided in the Supplementary materials.

\section{Compliance with ethical standards}

Conflict of interest The authors declare that they have no competing interests.

Ethics approval NA.

Consent to participate NA.

Consent for publication NA.

Code availability NA.

\section{References}

1. Brasó-Maristany F, Griguolo G, Pascual T, Paré L, Nuciforo P, Llombart-Cussac A, Bermejo B, Oliveira M, Morales S, Martínez N, Vidal M, Adamo B, Martínez O, Pernas S, López R, Muñoz M, Chic N, Galván P, Garau I, Manso L, Alarcón J, Martínez E, Gregorio S, Gomis RR, Villagrasa P, Cortés J, Ciruelos E, Prat 
A (2020) Phenotypic changes of HER2-positive breast cancer during and after dual HER2 blockade. Nat Commun 11:1-11. https://doi.org/10.1038/s41467-019-14111-3

2. Koboldt DC, Fulton RS, McLellan MD, Schmidt H, KalickiVeizer J, McMichael JF, Fulton LL, Dooling DJ, Ding L, Mardis ER, Wilson RK, Ally A, Balasundaram M, Butterfield YSN, Carlsen R, Carter C, Chu A, Chuah E, Chun HJE, Coope RJN, Dhalla N, Guin R, Hirst C, Hirst M, Holt RA, Lee D, Li HI, Mayo M, Moore RA, Mungall AJ, Pleasance E, Robertson AG, Schein JE, Shafiei A, Sipahimalani P, Slobodan JR, Stoll D, Tam A, Thiessen N, Varhol RJ, Wye N, Zeng T, Zhao Y, Birol I, Jones SJM, Marra MA, Cherniack AD, Saksena G, Onofrio RC, Pho NH, Carter SL, Schumacher SE, Tabak B, Hernandez B, Gentry J, Nguyen H, Crenshaw A, Ardlie K, Beroukhim R, Winckler W, Getz G, Gabriel SB, Meyerson M, Chin L, Kucherlapati R, Hoadley KA, Auman JT, Fan C, Turman YJ, Shi Y, Li L, Topal MD, He X, Chao HH, Prat A, Silva GO, Iglesia MD, Zhao W, Usary J, Berg JS, Adams M, Booker J, Wu J, Gulabani A, Bodenheimer T, Hoyle AP, Simons JV, Soloway MG, Mose LE, Jefferys SR, Balu S, Parker JS, Hayes DN, Perou CM, Malik S, Mahurkar S, Shen H, Weisenberger DJ, Triche T, Lai PH, Bootwalla MS, Maglinte DT, Berman BP, Van Den Berg DJ, Baylin SB, Laird PW, Creighton CJ, Donehower LA, Noble M, Voet D, Gehlenborg N, Di Cara D, Zhang J, Zhang H, Wu CJ, Yingchun Liu S, Lawrence MS, Zou L, Sivachenko A, Lin P, Stojanov P, Jing R, Cho J, Sinha R, Park RW, Nazaire MD, Robinson J, Thorvaldsdottir H, Mesirov J, Park PJ, Reynolds S, Kreisberg RB, Bernard B, Bressler R, Erkkila T, Lin J, Thorsson V, Zhang W, Shmulevich I, Ciriello G, Weinhold N, Schultz N, Gao J, Cerami E, Gross B, Jacobsen A, Sinha R, Aksoy BA, Antipin Y, Reva B, Shen R, Taylor BS, Ladanyi M, Sander C, Anur P, Spellman PT, Lu Y, Liu W, Verhaak RRG, Mills GB, Akbani R, Zhang N, Broom BM, Casasent TD, Wakefield C, Unruh AK, Baggerly K, Coombes K, Weinstein JN, Haussler D, Benz CC, Stuart JM, Benz SC, Zhu J, Szeto CC, Scott GK, Yau C, Paull EO, Carlin D, Wong C, Sokolov A, Thusberg J, Mooney S, $\mathrm{Ng} \mathrm{S}$, Goldstein TC, Ellrott K, Grifford M, Wilks C, Ma S, Craft B, Yan C, Hu Y, Meerzaman D, Gastier-Foster JM, Bowen J, Ramirez NC, Black AD, Pyatt RE, White P, Zmuda EJ, Frick J, Lichtenberg TM, Brookens R, George MM, Gerken MA, Harper HA, Leraas KM, Wise LJ, Tabler TR, McAllister C, Barr T, HartKothari M, Tarvin K, Saller C, Sandusky G, Mitchell C, Iacocca MV, Brown J, Rabeno B, Czerwinski C, Petrelli N, Dolzhansky O, Abramov M, Voronina O, Potapova O, Marks JR, Suchorska WM, Murawa D, Kycler W, Ibbs M, Korski K, Spychała A, Murawa P, Brzeziński JJ, Perz H, Łaźniak R, Teresiak M, Tatka H, Leporowska E, Bogusz-Czerniewicz M, Malicki J, Mackiewicz A, Wiznerowicz M, Van Le X, Kohl B, Viet Tien N, Thorp R, Van Bang N, Sussman H, Phu BD, Hajek R, Hung NP, Phuong TVT, Thang HQ, Khan KZ, Penny R, Mallery D, Curley E, Shelton C, Yena P, Ingle JN, Couch FJ, Lingle WL, King TA, Gonzalez-Angulo AM, Dyer MD, Liu S, Meng X, Patangan M, Waldman F, Stöppler H, Rathmell WK, Thorne L, Huang M, Boice L, Hill A, Morrison C, Gaudioso C, Bshara W, Daily K, Egea SC, Pegram MD, Gomez-Fernandez C, Dhir R, Bhargava R, Brufsky A, Shriver CD, Hooke JA, Campbell JL, Mural RJ, Hu H, Somiari S, Larson C, Deyarmin B, Kvecher L, Kovatich AJ, Ellis MJ, Stricker T, White K, Olopade O, Luo C, Chen Y, Bose R, Chang LW, Beck AH, Pihl T, Jensen M, Sfeir R, Kahn A, Chu A, Kothiyal P, Wang Z, Snyder E, Pontius J, Ayala B, Backus M, Walton J, Baboud J, Berton D, Nicholls M, Srinivasan D, Raman R, Girshik S, Kigonya P, Alonso S, Sanbhadti R, Barletta S, Pot D, Sheth M, Demchok JA, Shaw KRM, Yang L, Eley G, Ferguson ML, Tarnuzzer RW, Zhang J, Dillon LAL, Buetow K, Fielding P, Ozenberger BA, Guyer MS, Sofia HJ, Palchik JD (2012) Comprehensive molecular portraits of human breast tumours. Nature 490:61-70. https://doi.org/10. 1038/nature1 1412

3. Prat A, Pascual T, Adamo B (2017) Intrinsic molecular subtypes of HER2+ breast cancer. Oncotarget 8:73362-73363. https://doi. org/10.18632/oncotarget.20629

4. Gil-Gil MJ, Martinez-Garcia M, Sierra A, Conesa G, Del Barco S, González-Jimenez S, Villà S (2014) Breast cancer brain metastases: a review of the literature and a current multidisciplinary management guideline. Clin Transl Oncol 16:436-446. https://doi.org/ 10.1007/s12094-013-1110-5

5. Tanaka Y, Hirata M, Shinonome S, Torii M, Nezasa KI, Tanaka H (2018) Distribution analysis of epertinib in brain metastasis of HER2-positive breast cancer by imaging mass spectrometry and prospect for antitumor activity. Sci Rep 8:1-12. https://doi.org/10. 1038/s41598-017-18702-2

6. Mukherjee A, Dhadda AS, Shehata M, Chan S (2007) Lapatinib: a tyrosine kinase inhibitor with clinical role in breast cancer. Expert Opin Pharmacother 8:2189-2204. https://doi.org/10.1517/ 14656566.8.13.2189

7. Baltschukat S, Engstler BS, Huang A, Hao HX, Tam A, Wang HQ, Liang J, DiMare MT, Bhang HEC, Wang Y, Furet P, Sellers WR, Hofmann F, Schoepfer J, Tiedt R (2019) Capmatinib (INC280) is active against models of non-small cell lung cancer and other cancer types with defined mechanisms of MET activation. Clin Cancer Res 25:3164-3175. https://doi.org/10.1158/ 1078-0432.CCR-18-2814

8. Bekaii-Saab T, Kim R, Kim TW, O’Connor JM, Strickler JH, Malka D, Sartore-Bianchi A, Bi F, Yamaguchi K, Yoshino T, Prager GW (2019) Third- or later-line therapy for metastatic colorectal cancer: reviewing best practice. Clin Colorectal Cancer 18:e117-e129. https://doi.org/10.1016/j.clcc.2018.11.002

9. Murthy RK, Loi S, Okines A, Paplomata E, Hamilton E, Hurvitz SA, Lin NU, Borges V, Abramson V, Anders C, Bedard PL, Oliveira M, Jakobsen E, Bachelot T, Shachar SS, Muller V, Braga S, Duhoux FP, Greil R, Cameron D, Carey LA, Curigliano G, Gelmon K, Hortobagyi G, Krop I, Loibl S, Pegram M, Slamon D, Palanca-Wessels MC, Walker L, Feng W, Winer EP (2020) Tucatinib, trastuzumab, and capecitabine for HER2-positive metastatic breast cancer. N Engl J Med 382: 597-609. https://doi.org/10.1056/NEJMoa1914609

10. Dekker TJA (2020) Therapy for HER2-positive metastatic breast cancer. N Engl J Med 382:E98. https://doi.org/10.1056/ NEJMc2004854

11. Metzger Filho O, Leone JP, Li T, Tan-Wasielewski Z, Trippa L, Barry WT, Younger J, Lawler E, Walker L, Freedman RA, Tolaney SM, Krop I, Winer EP, Lin NU (2020) Phase I doseescalation trial of tucatinib in combination with trastuzumab in patients with HER2-positive breast cancer brain metastases. Ann Oncol 0. https://doi.org/10.1016/j.annonc.2020.05.014

12. Yuen K-S, Ye Z-W, Fung S-Y, Chan C-P, Jin D-Y (2020) SARSCoV-2 and COVID-19: the most important research questions. Cell Biosci 10:40. https://doi.org/10.1186/s13578-020-00404-4

13. Xu Z, Shi L, Wang Y, Zhang J, Huang L, Zhang C, Liu S, Zhao P, Liu H, Zhu L, Tai Y, Bai C, Gao T, Song J, Xia P, Dong J, Zhao J, Wang F-S (2020) Pathological findings of COVID-19 associated with acute respiratory distress syndrome. Lancet Respir Med 8: 420-422. https://doi.org/10.1016/S2213-2600(20)30076-X

14. Lake MA (2020) What we know so far: COVID-19 current clinical knowledge and research. Clin Med 20:124-127. https://doi. org/10.7861/clinmed.2019-coron

15. Wu R, Wang L, Kuo H-CD, Shannar A, Peter R, Chou PJ, Li S, Hudlikar R, Liu X, Liu Z, Poiani GJ, Amorosa L, Brunetti L, Kong A-N (2020) An update on current therapeutic drugs treating COVID-19. Curr Pharmacol Rep 6:56-70. https://doi.org/10. 1007/s40495-020-00216-7 
16. Gorbalenya A, Baker S, Baric R, de Groot R, Drosten C, Gulyaeva A, Haagmans B, Lauber C, Leontovich A, Neuman B, Penzar D, Perlman S, Poon L, Samborskiy D, Sidorov I, Sola I, Ziebuhr J (2020) Severe acute respiratory syndrome-related coronavirus : the species and its viruses - a statement of the Coronavirus Study Group. Nat Microbiol. https://doi.org/10.1101/2020.02.07. 937862

17. Harapan H, Itoh N, Yufika A, Winardi W, Keam S, Te H, Megawati D, Hayati Z, Wagner AL, Mudatsir M (2020) Coronavirus disease 2019 (COVID-19): a literature review. J Infect Public Health 13:667-673. https://doi.org/10.1016/j.jiph. 2020.03.019

18. Touret F, de Lamballerie X (2020) Of chloroquine and COVID19. Antivir Res 177:104762. https://doi.org/10.1016/j.antiviral. 2020.104762

19. Wang Y, Zhang D, Du G, Du R, Zhao J, Jin Y, Fu S, Gao L, Cheng Z, Lu Q, Hu Y, Luo G, Wang K, Lu Y, Li H, Wang S, Ruan S, Yang C, Mei C, Wang Y, Ding D, Wu F, Tang X, Ye X, Ye Y, Liu B, Yang J, Yin W, Wang A, Fan G, Zhou F, Liu Z, Gu $\mathrm{X}$, Xu J, Shang L, Zhang Y, Cao L, Guo T, Wan Y, Qin H, Jiang Y, Jaki T, Hayden FG, Horby PW, Cao B, Wang C (2020) Remdesivir in adults with severe COVID-19: a randomised, double-blind, placebo-controlled, multicentre trial. Lancet 395:15691578. https://doi.org/10.1016/S0140-6736(20)31022-9

20. Al-Otaibi JS, Almuqrin AH, Sheena Mary Y, Mary YS, Thomas R (2020) Modeling the conformational preference, spectral analysis and other quantum mechanical studies on three bioactive aminobenzoate derivatives and their SERS active graphene complexes. Polycycl Aromat Compd:1-11. https://doi.org/10.1080/ 10406638.2020.1827270

21. M.J. Frisch, G.W. Trucks, H.B. Schlegel, G.E. Scuseria, M.A. Robb, J.R. Cheeseman, G. Scalmani, V. Barone, B. Mennucci, G.A. Petersson, H. Nakatsuji, M. Caricato, X. Li, H.P. Hratchian, A.F. Izmaylov, J. Bloino, G. Zheng, J.L. Sonnenberg, M. Hada, M. Ehara, K. Toyota, R. Fukuda, J. Hasegawa, M. Ishida, T. Nakajima, Y. Honda, O. Kitao, H. Nakai, T. Vreven, J.A. Montgomery Jr., J.E. Peralta, F. Ogliaro, M. Bearpark, J.J. Heyd, E. Brothers, K.N. Kudin, V.N. Staroverov, R. Kobayashi, J. Normand, K. Raghavachari, A. Rendell, J.C. Burant, S.S. Iyengar, J. Tomasi, M. Cossi, N. Rega, J.M. Millam, M. Klene, J.E. Knox, J.B. Cross, V. Bakken, C. Adamo, J. Jaramillo, R. Gomperts, R.E. Stratmann, O. Yazyev, A.J. Austin, R. Cammi, C. Pomelli, J.W. Ochterski, R.L. Martin, K. Morokuma, V.G. Zakrzewski, G.A. Voth, P. Salvador, J.J. Dannenberg, S. Dapprich, A.D. Daniels, O. Farkas, J.B. Foresman, J. V Ortiz, J. Cioslowski, D.J. Fox, Gaussian09 Revision D.01, (2013)

22. Orio M, Pantazis DA, Neese F (2009) Density functional theory. Photosynth Res 102:443-453. https://doi.org/10.1007/s11120009-9404-8

23. Stephens PJ, Devlin FJ, Chabalowski CF, Frisch MJ (1994) Ab initio calculation of vibrational absorption and circular dichroism spectra using density functional force fields. J Phys Chem 98: 11623-11627. https://doi.org/10.1021/j100096a001

24. Foresman JB, Frisch Æ (2015) Exploring chemistry with electronic structure methods, 3rd ed., Gaussian, Inc.: Wallingford

25. Dunning TH (1989) Gaussian basis sets for use in correlated molecular calculations. I. The atoms boron through neon and hydrogen. J Chem Phys 90:1007-1023. https://doi.org/10.1063/1. 456153

26. Yanai T, Tew DP, Handy NC (2004) A new hybrid exchangecorrelation functional using the Coulomb-attenuating method (CAM-B3LYP). Chem Phys Lett 393:51-57. https://doi.org/10. 1016/J.CPLETT.2004.06.011

27. Okuno K, Shigeta Y, Kishi R, Miyasaka H, Nakano M (2012) Tuned CAM-B3LYP functional in the time-dependent density functional theory scheme for excitation energies and properties of diarylethene derivatives. J Photochem Photobiol A Chem 235:29-34. https://doi.org/10.1016/j.jphotochem.2012.03.003

28. O'boyle NM, Tenderholt AL, Langner KM (2008) CCLIB: a library for package-independent computational chemistry algorithms. J Comput Chem 29:839-845. https://doi.org/10.1002/jcc. 20823

29. Lu T, Chen F (2012) Multiwfn: a multifunctional wavefunction analyzer. J Comput Chem 33:580-592. https://doi.org/10.1002/ jcc. 22885

30. Burley SK, Berman HM, Bhikadiya C, Bi C, Chen L, Di Costanzo L, Christie C, Dalenberg K, Duarte JM, Dutta S, Feng Z, Ghosh S, Goodsell DS, Green RK, Guranović V, Guzenko D, Hudson BP, Kalro T, Liang Y, Lowe R, Namkoong H, Peisach E, Periskova I, Prlić A, Randle C, Rose A, Rose P, Sala R, Sekharan M, Shao C, Tan L, Tao Y-P, Valasatava Y, Voigt M, Westbrook J, Woo J, Yang H, Young J, Zhuravleva M, Zardecki C (2018) RCSB Protein Data Bank: biological macromolecular structures enabling research and education in fundamental biology, biomedicine, biotechnology and energy. Nucleic Acids Res 47:D464-D474. https://doi.org/10.1093/nar/gky1004

31. Schneidman-Duhovny D, Inbar Y, Nussinov R, Wolfson HJ (2005) PatchDock and SymmDock: servers for rigid and symmetric docking. Nucleic Acids Res 33:W363-W367. https://doi.org/ 10.1093/nar/gki481

32. Frisch MJ, Trucks GW, Schlegel HB, Scuseria GE, Robb MA, Cheeseman JR, Scalmani G, Barone V, Mennucci B, Petersson GA, Nakatsuji H, Caricato M, Li X, Hratchian HP, Izmaylov AF, Bloino J, Zheng G, Sonnenberg JL, Hada, M, Ehara M, Toyota K, Fukuda R, Hasegawa J, Ishida M, Nakajima T, Honda Y, Kitao O, Nakai H, Vreven T, Montgomery Jr., JA, Peralta JE, Ogliaro F, Bearpark M, Heyd JJ, Brothers E, Kudin KN, Staroverov VN, Kobayashi R, Normand J, Raghavachari K, Rendell A, Burant JC, Iyengar SS, Tomasi J, Coss M, Rega N, Millam JM, Klene M, Knox JE Cross JB, Bakken V, Adamo C, Jaramillo J, Gomperts R, Stratmann RE, Yazyev O, Austin AJ, Cammi R, Pomelli C, Ochterski JW, Martin RL, Morokuma K, Zakrzewski VG, Voth GA, Salvador, Dannenberg JJ, Dapprich S Daniels, A.D., Farkas, O., Foresman, J.B., Ortiz, J.V., Cioslowski, J. and Fox DJ (2010) Gaussian 09, Revision D.01. Gaussian Inc., Wallingford

33. Kümmel S, Kronik L (2008) Orbital-dependent density functionals: theory and applications. Rev Mod Phys 80:3-60. https:// doi.org/10.1103/RevModPhys.80.3

34. Zhang G, Musgrave CB (2007) Comparison of DFT methods for molecular orbital eigenvalue calculations. J Phys Chem A 111: 1554-1561. https://doi.org/10.1021/jp061633o

35. Teale AM, De Proft F, Tozer DJ (2008) Orbital energies and negative electron affinities from density functional theory: insight from the integer discontinuity. J Chem Phys 129:044110. https:// doi.org/10.1063/1.2961035

36. De Proft F, Sablon N, Tozer DJ, Geerlings P (2007) Calculation of negative electron affinity and aqueous anion hardness using Kohn-Sham HOMO and LUMO energies. In: Faraday Discuss., Royal Society of Chemistry, pp. 151-159. https://doi.org/10. 1039/b605302p

37. Louis E, San-Fabián E, Díaz-García MA, Chiappe G, Vergés JA (2017) Are Electron affinity and ionization potential intrinsic parameters to predict the electron or hole acceptor character of amorphous molecular materials? J Phys Chem Lett 8:2445-2449. https://doi.org/10.1021/acs.jpclett.7b00681

38. Zhan CG, Nichols JA, Dixon DA (2003) Ionization potential, electron affinity, electronegativity, hardness, and electron excitation energy: molecular properties from density functional theory orbital energies. J Phys Chem A 107:4184-4195. https://doi.org/ 10.1021/jp0225774 
39. Parr RG, Pearson RG (1983) Absolute hardness: companion parameter to absolute electronegativity. J Am Chem Soc 105:75127516. https://doi.org/10.1021/ja00364a005

40. Politzer P, Murray JS (2018) An Occam's razor approach to chemical hardness: lex parsimoniae. J Mol Model 24:332. https://doi. org/10.1007/s00894-018-3864-8

41. Xu H, Xu DC, Wang Y (2017) Natural indices for the chemical hardness/softness of metal cations and ligands:7185-7193. https:// doi.org/10.1021/acsomega. $7 \mathrm{~b} 01039$

42. Schmider HL, Becke AD (2000) Chemical content of the kinetic energy density. J Mol Struct THEOCHEM 527:51-61. https://doi. org/10.1016/S0166-1280(00)00477-2

43. Pearson RG (1988) Absolute electronegativity and hardness: application to inorganic chemistry. Inorg Chem 27:734-740. https:// doi.org/10.1021/ic00277a030

44. Chattaraj PK, Sarkar U, Roy DR (2006) Electrophilicity index. Chem Rev 106:2065-2091. https://doi.org/10.1021/cr040109f

45. Chattaraj PK, Giri S (2009) Electrophilicity index within a conceptual DFT framework. Annu Rep Prog Chem, Sect C: Phys Chem 105:13-39. https://doi.org/10.1039/B802832J

46. Domingo LR, Ríos-Gutiérrez M, Pérez P (2016) Applications of the conceptual density functional theory indices to organic chemistry reactivity. Molecules. 21:748. https://doi.org/10.3390/ molecules 21060748

47. Al-Otaibi JS, Mary YS, Mary YS, Thomas R (2019) Quantum mechanical and photovoltaic studies on the cocrystals of hydrochlorothiazide with isonazid and malonamide. J Mol Struct 1197: 719-726. https://doi.org/10.1016/j.molstruc.2019.07.110

48. Al-Otaibi JS, Sheena Mary Y, Shyma Mary Y, Panicker CY, Thomas R (2019) Cocrystals of pyrazinamide with ptoluenesulfonic and ferulic acids: DFT investigations and molecular docking studies. J Mol Struct 1175:916-926. https://doi.org/ 10.1016/j.molstruc.2018.08.055

49. Al-Otaibi JS, Mary YS, Armaković S, Thomas R (2020) Hybrid and bioactive cocrystals of pyrazinamide with hydroxybenzoic acids: detailed study of structure, spectroscopic characteristics, other potential applications and noncovalent interactions using SAPT. J Mol Struct 1202:127316. https://doi.org/10.1016/j. molstruc.2019.127316

50. Majumdar D, Agrawal Y, Thomas R, Ullah Z, Santra MK, Das S, Pal TK, Bankura K, Mishra D (2020) Syntheses, characterizations, crystal structures, DFT/TD-DFT, luminescence behaviors and cytotoxic effect of bicompartmental Zn (II)-dicyanamide Schiff base coordination polymers: an approach to apoptosis, autophagy and necrosis type classical cell death. Appl Organomet Chem 34. https://doi.org/10.1002/aoc.5269

51. Majumdar D, Das S, Thomas R, Ullah Z, Sreejith SS, Das D, Shukla P, Bankura K, Mishra D (2019) Syntheses, X-ray crystal structures of two new $\mathrm{Zn}$ (II)-dicyanamide complexes derived from $\mathrm{H} 2$ vanen-type compartmental ligands: investigation of thermal, photoluminescence, in vitro cytotoxic effect and DFTTDDFT studies. Inorg Chim Acta 492:221-234

52. Klamt A, Moya C, Palomar J (2015) A comprehensive comparison of the IEFPCM and SS(V)PE continuum solvation methods with the COSMO approach. J Chem Theory Comput 11:4220 4225. https://doi.org/10.1021/acs.jctc.5b00601

53. Hedley GJ, Ruseckas A, Samuel IDW (2017) Light harvesting for organic photovoltaics. Chem Rev 117:796-837. https://doi.org/ 10.1021/acs.chemrev.6b00215

54. Rao DJ, Mary YS, Mary YS, Resmi KS, Thomas R (2019) Structure, spectral features, bioactivity and light harvesting properties of methyl and dimethyl anthracene: experimental and first principle studies. Polycycl Aromat Compd:1-15. https://doi.org/ 10.1080/10406638.2019.1709083

55. Scholes GD (2017) Introduction: light harvesting. Chem Rev 117: 247-248. https://doi.org/10.1021/acs.chemrev.6b00826
56. Curutchet C, Mennucci B (2017) Quantum chemical studies of light harvesting. Chem Rev 117:294-343. https://doi.org/10. 1021/acs.chemrev.5b00700

57. Majumdar D, Das S, Thomas R, Ullah Z, Sreejith SS (2019) Syntheses, X-ray crystal structures of two new Zn ( II ) dicyanamide complexes derived from $\mathrm{H} 2$ vanen-type compartmental ligands : Investigation of thermal, photoluminescence, in vitro cytotoxic e ff ect and DFT-TDDFT studies. Inorg Chim Acta 492:221-234. https://doi.org/10.1016/j.ica.2019.04.041

58. Thadathil DA, Varghese S, Akshaya KB, Thomas R, Varghese A (2019) An insight into photophysical investigation of (E)-2fluoro-N'-(1-(4-nitrophenyl) ethylidene) benzohydrazide through solvatochromism approaches and computational studies. J Fluoresc 29:1013-1027

59. Irfan A, Imran M, Thomas R, Mumtaz MW, Basra MAR, Ullah S, Assiri MA, Al-Sehemi AG (2020) An exploration of the optoelectronic nature of 4,4-difluoro-8-(C4H3X)-4-bora-3a,4a-diaza-sindacene $(\mathrm{X}=\mathrm{O}, \mathrm{S}, \mathrm{Se})$ (BODIPY) systems. J Comput Electron. https://doi.org/10.1007/s10825-020-01597-0

60. Irfan A, Imran M, Thomas R, Basra MAR, Ullah S, Al-Sehemi AG, Assiri MA (2020) Exploring the effect of oligothiophene and acene cores on the optoelectronic properties and enhancing $\mathrm{p}$ - and n-type ability of semiconductor materials. J Sulfur Chem:1-13. https://doi.org/10.1080/17415993.2020.1830401

61. Irfan A, Imran M, Thomas R, Mumtaz MW, Qayyum MA, Ullah S, Assiri MA, Al-Sehemi AG (2020) Exploration of electronic nature and intrinsic mobility of 10-(1,3-dithiol-2ylidene)anthracene based organic semiconductor materials. Optik (Stuttg):165530. https://doi.org/10.1016/j.ijleo.2020. 165530

62. Andijani N, Al-Qurashi O, Wazzan N, Irfan A (2019) Modeling of efficient pyrene-core substituted with electron-donating groups as hole-transporting materials in perovskite solar cells. Sol Energy 188:898-912. https://doi.org/10.1016/j.solener.2019.06.074

63. Irfan A, Assiri M, Al-Sehemi AG (2018) Exploring the optoelectronic and charge transfer performance of diaza[5]helicenes at molecular and bulk level. Org Electron 57:211-220. https://doi. org/10.1016/j.orgel.2018.03.022

64. Irfan A, Al-Sehemi AG, Assiri MA, Ullah S (2020) Exploration the effect of metal and electron withdrawing groups on charge transport and optoelectronic nature of schiff base $\mathrm{Ni}(\mathrm{II}), \mathrm{Cu}(\mathrm{II})$ and $\mathrm{Zn}$ (II) complexes at molecular and solid-state bulk scales. Mater Sci Semicond Process 107:104855. https://doi.org/10. 1016/j.mssp.2019.104855

65. Wazzan N, Irfan A (2020) Promising architectures modifying the $D-\pi$-A architecture of 2,3-dipentyldithieno[3,2-f:2', $3^{\prime}$ $\mathrm{h}]$ quinoxaline-based dye as efficient sensitizers in dye-sensitized solar cells: a DFT study. Mater Sci Semicond Process 120: 105260. https://doi.org/10.1016/j.mssp.2020.105260

66. Kavitha KR, Mary YS, Fernandez A, Anu Priya S, Mary YS, Thomas R (2019) Single crystal XRD, DFT investigations and molecular docking study of 2- ((1,5-dimethyl-3-oxo-2-phenyl-2, 3-dihydro-1H-pyrazol-4-yl)amino)naphthalene-1,4-dione as a potential anti- cancer lead molecule. Comput Biol Chem 78:153164. https://doi.org/10.1016/j.compbiolchem.2018.11.022

67. Reed AE, Curtiss LA, Weinhold F (1988) Intermolecular interactions from a natural bond orbital, donor-acceptor viewpoint. Chem Rev 88:899-926. https://doi.org/10.1021/cr00088a005

68. Weinhold F (2012) Natural bond orbital analysis: a critical overview of relationships to alternative bonding perspectives. J Comput Chem 33:2363-2379. https://doi.org/10.1002/jcc.23060

69. Matondo A, Thomas R, Tsalu PV, Mukeba CT, Mudogo V (2019) $\alpha$-methylation and $\alpha$-fluorination electronic effects on the regioselectivity of carbonyl groups of uracil by $\mathrm{H}$ and triel bonds in the interaction of $\mathrm{U}, \mathrm{T}$ and $5 \mathrm{FU}$ with $\mathrm{HCl}$ and $\mathrm{TrH} 3(\mathrm{Tr}=\mathrm{B}, \mathrm{Al}) . \mathrm{J}$ 
Mol Graph Model 88:237-246. https://doi.org/10.1016/j.jmgm. 2019.02.006

70. Dunnington BD, Schmidt JR (2012) Generalization of natural bond orbital analysis to periodic systems: applications to solids and surfaces via plane-wave density functional theory. J Chem Theory Comput 8:1902-1911. https://doi.org/10.1021/ct300002t

71. Glendening ED, Landis CR, Weinhold F (2012) Natural bond orbital methods. WIREs Comput Mol Sci 2:1-42. https://doi. org/10.1002/wcms.51

72. Hosna S, Janzen DE, Mary YS, Resmi KS, Thomas R, Mohamed R, Wajda S (2018) Molecular structure, spectroscopic, dielectric and thermal study, nonlinear optical properties, natural bond orbital, HOMO-LUMO and molecular docking analysis of (C6Cl2O4) (C10H14N2F)2-2H2O. Spectrochim Acta A Mol Biomol Spectrosc 204:328-339. https://doi.org/10.1016/J.SAA. 2018.06.062

73. John AM, Jose J, Thomas R, Thomas KJ, Balakrishnan SP (2020) Spectroscopic and TDDFT investigation of highly selective fluoride sensors by substituted acyl hydrazones. Spectrochim Acta A Mol Biomol Spectrose 118329. https://doi.org/10.1016/j.saa. 2020.118329

74. Murray JS, Politzer P (1998) Average local ionization energies: significance and applications. In: C.B.T.-T, Párkányi CC (eds) Theor. Org. Chem. Elsevier, pp 189-202. https://doi.org/10. 1016/S1380-7323(98)80009-5

75. Sjoberg P, Murray JS, Brinck T, Politzer P (1990) Average local ionization energies on the molecular surfaces of aromatic systems as guides to chemical reactivity. Can J Chem 68:1440-1443. https://doi.org/10.1139/v90-220

76. Politzer P, Abu-Awwad F, Murray JS (1998) Comparison of density functional and Hartree-Fock average local ionization energies on molecular surfaces. Int J Quantum Chem 69:607-613. https:// doi.org/10.1002/(SICI)1097-461X(1998)69:4<607::AIDQUA18>3.0.CO;2-W

77. Politzer P, Murray JS, Bulat FA (2010) Average local ionization energy: a review. J Mol Model 16:1731-1742. https://doi.org/10. 1007/s00894-010-0709-5

78. Fuster F, Sevin A, Silvi B (2000) Topological analysis of the electron localization function (ELF) applied to the electrophilic aromatic substitution. J Phys Chem A 104:852-858. https://doi. org $/ 10.1021 / \mathrm{jp} 992783 \mathrm{k}$

79. Fuentealba P, Chamorro E, Santos JC (2007) Chapter 5 Understanding and using the electron localization function. In: A.B.T.-T, Toro-Labbé CC (eds) Theor. Asp. Chem. React. Elsevier, pp 57-85. https://doi.org/10.1016/S1380-7323(07) 80006-9

80. Gibbs GV, Cox DF, Boisen Jr MB, Downs RT, Ross NL (2003) The electron localization function: a tool for locating favorable proton docking sites in the silica polymorphs. Phys Chem Miner 30:305-316. https://doi.org/10.1007/s00269-003-0318-2

81. Jacobsen H (2008) Localized-orbital locator (LOL) profiles of chemical bonding. Can J Chem 86:695-702. https://doi.org/10. 1139/v08-052

82. Tsirelson V, Stash A (2002) Analyzing experimental electron density with the localized-orbital locator. Acta Crystallogr B 58:780 785. https://doi.org/10.1107/S0108768102012338

83. Politzer P, Murray JS (1991) Molecular electrostatic potentials and chemical reactivity. Rev Comput Chem:273-312. https://doi.org/ 10.1002/9780470125793.ch7

84. Politzer P, Lane P, Concha MC (2002) Atomic and molecular energies in terms of electrostatic potentials at nuclei. Int $\mathrm{J}$ Quantum Chem 90:459-463. https://doi.org/10.1002/qua.10105

85. Breneman CM, Martinov M (1996) 3 - The use of electrostatic potential fields in QSAR and QSPR. In: Murray JS, K.B.T.-T, Sen CC (eds) Mol. Electrost. Potentials. Elsevier, pp 143-179. https:// doi.org/10.1016/S1380-7323(96)80043-4
86. Politzer P, Laurence PR, Jayasuriya K (1985) Molecular electrostatic potentials: an effective tool for the elucidation of biochemical phenomena. Environ Health Perspect 61:191-202. https://doi. org/10.1289/ehp.8561191

87. Orozco M, Luque FJ (1996) Generalization of the molecular electrostatic potential for the study of noncovalent interactions. In: Murray JS, K.B.T.-T, Sen CC (eds) Mol. Electrost. Potentials. Elsevier, pp 181-218. https://doi.org/10.1016/S1380-7323(96) 80044-6

88. Del Campo JM, Gázquez JL, Alvarez-Mendez RJ, Vela A (2012) The reduced density gradient in atoms. Int J Quantum Chem 112: 3594-3598. https://doi.org/10.1002/qua.24241

89. Boto RA, Piquemal JP, Contreras-García J (2017) Revealing strong interactions with the reduced density gradient: a benchmark for covalent, ionic and charge-shift bonds. Theor Chem Accounts 136:1-9. https://doi.org/10.1007/s00214-017-2169-9

90. De Silva P, Corminboeuf C (2014) Simultaneous visualization of covalent and noncovalent interactions using regions of density overlap. J Chem Theory Comput 10:3745-3756. https://doi.org/ $10.1021 / \mathrm{ct} 500490 \mathrm{~b}$

91. Zupan A, Perdew JP, Burke K, Causà M (1997) Density-gradient analysis for density functional theory: application to atoms. Int $\mathrm{J}$ Quantum Chem 61:835-845. https://doi.org/10.1002/(SICI)1097461X(1997)61:5<835::AID-QUA9>3.0.CO;2-X

92. Zhao H, Ren Fd, Wang YH (2015) Theoretical insight into the $\mathrm{BH} 3 \cdot \mathrm{HCN}$ adsorption on the $\mathrm{Co}(100)$ and $\mathrm{Co}(110)$ surfaces as hydrogen storage. J Mol Model 23(4):126. https://doi.org/10. 1007/s00894-017-3298-8

93. Rong C, Wang B, Zhao D, Liu S (2020) Information-theoretic approach in density functional theory and its recent applications to chemical problems. WIREs Comput Mol Sci 10:e1461. https:// doi.org/10.1002/wcms. 1461

94. Grimme S, Schreiner PR (2018) Computational chemistry: the fate of current methods and future challenges. Angew Chem Int Ed 57: 4170-4176. https://doi.org/10.1002/anie.201709943

95. Lefebvre C, Rubez G, Khartabil H, Boisson JC, Contreras-García J, Hénon E (2017) Accurately extracting the signature of intermolecular interactions present in the NCI plot of the reduced density gradient: versus electron density. Phys Chem Chem Phys 19: 17928-17936. https://doi.org/10.1039/c7cp02110k

96. Priya YS, Rao KR, Chalapathi PV, Veeraiah A, Srikanth KE, Mary YS, Thomas R (2020) Intricate spectroscopic profiling, light harvesting studies and other quantum mechanical properties of 3 phenyl-5-isooxazolone using experimental and computational strategies. J Mol Struct 1203:127461. https://doi.org/10.1016/j. molstruc.2019.127461

97. Srikanth KE, Veeraiah A, Pooventhiran T, Thomas R, Solomon KA, Raju CJS, Latha JNL (2020) Detailed molecular structure (XRD), conformational search, spectroscopic characterization (IR, Raman, UV, fluorescence), quantum mechanical properties and bioactivity prediction of a pyrrole analogue. Heliyon. 6:e04106

98. RCSB PDB - 6M03: the crystal structure of COVID-19 main protease in apo form (n.d.). https://www.wwpdb.org/pdb?id= pdb_00006m03

99. Mesecar AD (2020) RCSB PDB - 6W63: structure of COVID-19 main protease bound to potent broad-spectrum non-covalent inhibitor X77, RCSB. https://doi.org/10.2210/pdb6W63/pdb

100. Wang Q, Zhang Y, Wu L, Niu S, Song C, Zhang Z, Lu G, Qiao C, Hu Y, Yuen K-Y, Wang Q, Zhou H, Yan J, Qi J (2020) Structural and functional basis of SARS-CoV-2 entry by using human ACE2. Cell 181:894-904.e9. https://doi.org/10.1016/j.cell.2020. 03.045

Publisher's note Springer Nature remains neutral with regard to jurisdictional claims in published maps and institutional affiliations. 